Research Article/Araştırma Makalesi

\title{
An Action Research Aligned with the REACT+G Teaching Approach: "Thales' Intercept Theorem"
}

\author{
Mehmet İhsan YURTYAPAN *1 (D) Menekşe Seden TAPAN-BROUTIN 2 (D) Gül KALELİ-YILMAZ 3 \\ ${ }^{1}$ Bursa Uludă̆ University, Education Faculty, Bursa, Turkey asimptot10@yandex.com \\ 2 Bursa Uludă̆ University, Education Faculty, Bursa, Turkey, tapan@uludag.edu.tr \\ ${ }^{3}$ Bursa Uludă̆ University, Education Faculty, Bursa, Turkey, gulkaleli@uludag.edu.tr \\ * Corresponding Author: asimptot10@yandex.com
}

\begin{tabular}{|c|c|}
\hline Article Info & Abstract \\
\hline $\begin{array}{l}\text { Keywords: Context-based learning, } \\
\text { REACT learning strategy, REACT+G } \\
\text { learning strategy, geometry } \\
\text { do } \mathbf{1 0 . 1 8 0 0 9 / j c e r . 6 8 4 8 0 8} \\
\text { Publication Language: Turkish }\end{array}$ & $\begin{array}{l}\text { The aim of this study is to examine the reflections from the practices } \\
\text { prepared for teaching the subject of "Thales' Intercept Theorem" } \\
\text { according to the REACT+G teaching strategy proposed as a different } \\
\text { alternative to the REACT teaching strategy. In the study, action } \\
\text { research method, one of the qualitative research methods, was used. } \\
\text { The sample of the study consists of } 10 \text { high school students studying in } \\
\text { the } 11 \text { th grade. The study group was determined by an easily accessible } \\
\text { sampling method. Content analysis was used in the analysis of the data } \\
\text { obtained through observation, video-sound recording and student } \\
\text { worksheets. The "Generalization Stage (+G)" proposed in the research } \\
\text { gave the teacher the opportunity to overcome the shortcomings of the } \\
\text { students in accordance with the constructivist learning approach, } \\
\text { different from the REACT teaching strategy. In order to examine the } \\
\text { effects of the REACT+G teaching strategy, researchers are } \\
\text { recommended experimental studies at different levels. }\end{array}$ \\
\hline
\end{tabular}

open $\bigcirc$ access

To cite this article: Yurtyapan, M.İ., Tapan-Broutin, M.S., \& KaleliYılmaz, G. (2020). REACT+G öğretim yaklaşımına yönelik bir eylem araştırmasi: "thales paralellik ilkesi". Journal of Computer and Education Research, 8(15), 241-273. DOI:10.18009/jcer.684808

\section{REACT+G Öğretim Yaklaşımına Yönelik Bir Eylem Araştırması: “Thales Paralellik İlkesi”}

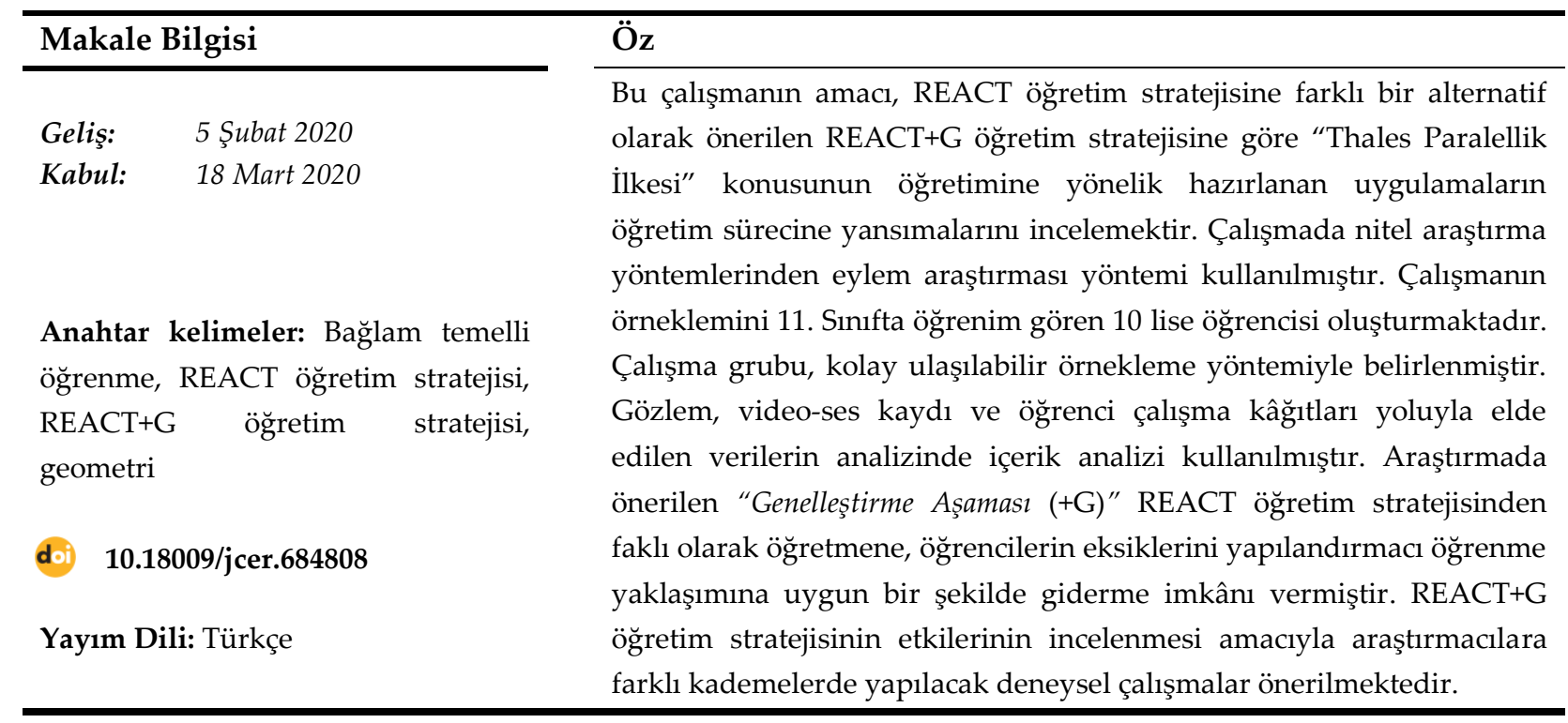




\section{Summary}

\section{REACT+G Action Research for Teaching Approach: “Thales' Intercept Theorem"}

\section{Introduction}

There is a constructivist learning philosophy on the basis of a context-based learning approach that aims to use familiar contexts to relate students' experiences in daily life with new information (Berns \& Erickson, 2001; Crawford, 2001; Lynch \& Padilla, 2000). The most well-known teaching strategy developed based on the context-based approach is the REACT strategy (Texas Collaborative for Teaching Excellence, 2007; Ültay \& Çalık, 2011). The name of the REACT strategy was formed from the first letters of the English equivalents of the stages of implementation of this strategy, Relating, Experiencing, Applying, Cooperating and Transferring. In order to increase the effectiveness of REACT in a structure that allows the student to construct knowledge, it is considered appropriate to add the Generation stage. The generalization stage is systematically designed by the teacher, allowing specific learning to take place and evaluate the process with the student. At this stage, the teacher presents the remarkable answers given by the group or individually to the students' attention in all the current stages of REACT and examines them together. Thus, informal information obtained by students at each stage is examined with the teacher and a generalization is reached. This study is important since the REACT strategy will be made a complete model with the addition of the generalization stage, which is considered to be incomplete. For this reason, the aim of the study is to describe the experiences in the teaching process of the "Thales' Intercept Theorem" subject of the REACT+G approach developed by the researcher.

\section{Results}

As a result of the teaching of "Thales' Intercept Theorem" subject, which was carried out by adopting the REACT $+\mathrm{G}$ teaching strategy, it was seen that all of the students were successful in solving their context-based problems that they faced during the process of relating, applying and transferring. In the experience and collaboration stage, it was 
determined that some students experienced difficulties in solving problem situations during the teaching process. In the generalization stage, the students and the teacher discussed the problem situations in the entire teaching process together. While making the generalization of the experience and collaboration stage, the deficiencies in the solutions of some groups were noticed by the students.

\section{Method}

This study was carried out with the action research method, which is one of the qualitative research methods. The study group of the research consists of 10 students studying in the 11th grade. While determining the participants, easy sampling method was used. Content analysis technique was used in the analysis of the data obtained through observation, video-sound recording and student worksheets.

\section{Discussion and Conclusion}

As a result of the teaching of the "Thales' Intercept Theorem" topic, which was carried out by adopting the REACT+G teaching strategy in the study, it was determined that some students had difficulties in solving their problem situations while they were successful in solving the contextual problems they encountered during the process of associating, applying and transferring. It is suggested that the generalization stage should be added to the REACT strategy in the study in order to overcome the learning difficulties that students experience at these stages. A football character, especially in the immediate vicinity of the students, is used by using the "football" context in order to draw the attention of the students in the relating stage from the stages where all of the students are successful. This has enabled the relating stage to take place effectively. Therefore, it may be suggested that the contexts to be created in the relating stage should be selected from the people or events in the immediate surroundings that each student follows, to provide more effective results. It was observed that the stages before these stages were effective in the success of all students in the application and transfer stages. It is thought that the students' taking responsibility in teaching by sharing tasks during the experience and collaboration stage is a factor in the success of the students. Therefore, every stage should be designed to give students responsibility in their own learning as much as possible. 


\section{Giriş}

Ülkelerin birbirleriyle olan rekabetinde bilim her zaman önemli bir argüman olmuştur. Bilim sayesinde ekonomik, sosyolojik ve çevresel içerikli pek çok soruna hızlı teknolojik çözümler üretilebilmektedir. Son yıllarda gerçekleşen gelişmelere bakıldığında ise eğitimin amacl; çağı, bilimsel ve teknolojik gelişmeleri takip edebilen, özümseyen güçlü bir gelecek inşa etmektir (Cansoy, 2018). Bunun için de bireylerde donanımlı bir matematik bilgisinin bulunması gerekmektedir. Matematik eğitimi, bireylerin problem çözme becerilerini geliştirmelerini, yaşadığı dünyanın yanı sıra evreni anlayabilmelerini ve açıklayabilmelerini sağladığı için önemli bir konuma sahiptir (Aydoğdu \& Ayaz, 2008). Bu sebeple ülkeler matematik eğitimlerinin niteliğini arttırabilmek için devamlı bir arayış içerisindedirler. Dolayısıyla yeni araştırmalar yapılarak öğretim programları güncellenmektedir. Öğretim programında yapılan güncellemeler incelendiğinde, programlar öğrencilerin matematik okuryazarı olabilmelerinin önemine işaret etmektedir (Milli Eğitim Bakanlığ1 [MEB], 2018).

Matematik okuryazarı olan kişiler, araştırma sorgulama yapabilme, eleştirel düşünebilme, problem çözme ve karar verme becerilerine hâkimdirler (Tekin \& Tekin, 2004). Bunun yanı sıra günlük hayatla matematik konuları arasında ilişki kurabilme, yaşadıkları çevre ile ilgili merak duygusu içerisinde hareket edebilme ve öğrenmenin yaşam boyu devam eden bir süreç olduğunun farkında olmada bu bireylerin sahip olduğu niteliklerdir (Uysal \& Yenilmez, 2011). Öğrencilerde beklenen bu tip özelliklerin oluşturulabilmesi, bilginin öğrenci tarafından içselleştirilebilmesi ve öğrenmenin sorumluluğunu alıp bilgiyi kendisinin yapılandırması ile mümkündür. Günümüz matematik öğretiminin başlıca sorunları arasında; bilginin öğrencilere aşırı yüklenmesi, bilimsel bilgi ile yaşam arasındaki bağın kurulamaması, bilgilerin öğrenci tarafından farklı durumlara ya da ortamlara aktarılamaması gibi birçok sorun sıralanabilir (Civelek, Meder, Tüzen \& Aycan, 2003). Matematik eğitiminde karşılaşılan bu problemleri gidermenin yanı sıra eğitimin kalitesini artırmak için bağlam temelli öğrenme yaklaşımı oldukça yaygın olarak kullanılmaya başlanmiştır.

Öğrencilerin, yeni bilgilerle günlük hayattaki deneyimlerini ilişkilendirmede tanıdık bağlamlar kullanılmasını hedefleyen bağlam temelli öğrenme yaklaşımı temelinde yapılandırmacı öğrenme felsefesi vardır (Berns \& Erickson, 2001; Crawford, 2001; Lynch \& 
Padilla, 2000). Bağlam temelli öğrenme yaklaşımında öğrencilerin kazanmalarını istediğimiz bilimsel içerik, bilgiye ihtiyaç duydukları bir bağlama dayandırılmalı ve buna yönelik bir öğrenme ortamı oluşturulmalıdır. Tasarlanan ortamlarda öğrenciler öğrenmenin sorumluluğunu alarak, yaparak yaşayarak öğreneceklerdir. Bu yolla öğrenilen bilgilerin arasındaki uyumun sağlanmasının yanı sıra (Pilot \& Bulte, 2006), öğrencilerin derse olan ilgi ve motivasyonları da artacaktır (Tekbıyık, 2010).

Bağlam temelli öğretim yaklaşımının uygulanabildiği farklı yöntemler ve teknikler (işbirlikçi öğrenme, drama, 5E, 7E öğrenme döngüleri, probleme dayalı öğrenme vb.) bulunmaktadır. Bunların içerisinde bağlam temelli öğrenme yaklaşımını esas alarak geliştirilen en tanınmış strateji ise REACT stratejisidir (Karamustafaoğlu \& Tutar, 2018; Texas Collaborative for Teaching Excellence, 2007; Ültay \& Çalık, 2011). The Center of Occupational Research and Development [Mesleki Araştırma ve Gelişim Merkezi, CORD] organizasyonu 1998 yılında bağlamsal öğrenme ve öğretme konusunda projeler geliştiren ve REACT stratejisinden bahseden ilk kuruluştur. Hull (1999), Crawford (2001) ve Navarra (2006) araştırmalarında bir öğretim modeli olarak kullandıkları REACT’1 tanıtmışlardır. REACT stratejisi ismini, bu stratejinin uygulama aşamaları olan İlişkilendirme (Relating), Tecrübe etme (Experiencing), Uygulama (Applying), İşbirliği (Cooperating) ve Transfer etme (Transferring) aşamalarının İngilizce karşıllklarının ilk harflerinden oluşturulmuştur. Bu aşamalar kısaca şu şekilde açıklanabilir:

1. İlişkilendirme (Relating): Konu ile bağlam arasında bir ilişki kurarak öğrenilecek yeni bilgiye öğrencinin dikkatinin kendiliğinden yoğunlaşmasını sağlayan ilk aşamadır. Bu aşamada öğrenilecek bilginin, önceden var olan bilgilerle ve günlük hayattan seçilen bağlamlarla ilişkilendirilmesi gerekmektedir.

2. Tecrübe etme (Experiencing): Öğrenciler gerçek yaşam durumları bağlamı ve konu ile ilişkili etkinliklerle tecrübeler edinerek, bularak, icat ederek ve yaparak yaşayarak öğrenirler (Navarra, 2006). Bu aşamada öğrenciler kendi verilerini topladıklarında problem hakkında bir sahiplenme duygusu hissederek süreci aktif olarak takip ederler.

3. Uygulama (Applying): Öğrencilerin konu içerisindeki kavramları anlamaları ve motive olmaları için aşina olunan bağlamlar üzerinden ilgilerini çekebilecek durumlar ve örnekler sunulur. Durumlarla ilgili problemlere çözüm üretmeleri 
sağlanır. Konu içerisindeki kavramları mevcut duruma uygularlar. Bu sayede öğrenciler bilgiyi özümserler ve anlama seviyeleri yükselir (Ingram, 2003).

4. İşbirliği (Cooperating): Öğrenciler bu aşamada günlük yaşam içerikli senaryolara çözüm üretmek veya araştırma yapmak amacıyla grup içerisinde bilgi paylaşımında bulunurlar. Fikirlerini savunurlar ve arkadaşlarıyla yoğun bir şekilde iletişim kurarlar. Bu sayede sosyal etkileşim ve işbirlikli bir öğrenme ortamı oluşturulur.

5. Transfer etme (Transferring): Önceki aşamalarda öğrenilen bilginin farklı yaşamsal problemlere çözüm üretirken transfer edildiği aşamadır. Bu aşamada öğrenci tartışılmayan bir bağlam veya durumla karşılaşması gerekmektedir (CORD, 1998).

REACT modelinde aşamalar sıralı bir şekilde uygulanabileceği gibi, Şekil 1'de gösterilen bir döngüsellik içerisinde tasarlanıp ihtiyaç halinde transfer basamağından tekrar ilişkilendirme basamağına dönülebilir. Ayrıca ara basamaklar olan tecrübe etme, uygulama ve işbirliği iç içe geçmiş şekilde de kullanılabilir (Navarra, 2006).

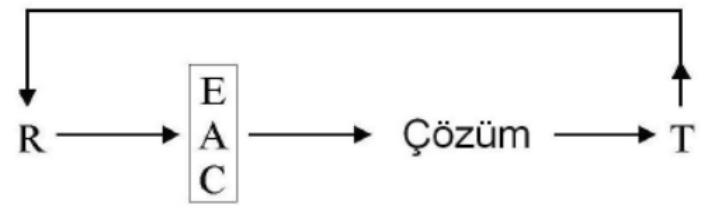

Şekil 1. REACT modelinin döngüsel yapısı (Navarra, 2006)

REACT modeli her aşamasında bağlam temelli hareket edilmesini zorunlu kılmaktadır. Öğrenmenin sorumluluğunu öğrenciye devretmekte ve öğretmeni geri planda kalacak şekilde adeta bir moderatör konumuna yerleştirmektedir (Ültay, 2012). Bu yönüyle ise REACT öğretim stratejisi esneklikten uzak ve uygulayıcılar tarafından yapılandırmacılığın temellerinin bozulmayacağı şekilde kuralları olan bir model olarak karşımıza çıkmaktadır. Ancak REACT'a yönelik yapılan çalışmalar incelendiğinde stratejinin uygulanması sırasında karşılaşılan problemler ve REACT stratejisinin geliştirilmesi gerekliliği ifade edilmiştir (Coştu, 2009; Ültay, 2012). Coştu (2009), REACT stratejisi ile ilgili yapmış olduğu araştırmanın sonuçlarından yola çıkarak, stratejide aksayan noktaların giderilmesi adına açıklama ve tartışma aşamaları eklenerek bu konuda daha detaylı çalışmalar yapılması gerektiğini önermiştir. Ayrıca Ültay (2012) tarafından da REACT stratejisine açıklama aşaması (Explaining) eklenerek stratejinin REEACT (RelatingExperiencing-Explaining-Applying-Cooperating-Transferring) şeklinde olması gerektiği belirtilmektedir. Ültay'a (2012) göre tecrübe etme (Experiencing) basamağından sonra 
açıklama (Explaining) basamağının eklenmesi öğrencilerin bilgilerini tecrübe ettikten sonra öğrenme sürecinde oluşabilecek alternatif kavramların giderilmesi bakımından faydalı olabileceği düşünülmektedir.

Öğretmen adaylarının açıklama destekli REACT öğretim stratejisi ile ilgili görüşlerinin belirlenmesi amacıyla Ültay ve Alev (2017) tarafından yapılan bir çalışmada ise eğitim öğretim esnasında özellikle açıklama ilkesinin eksikliğinin yaşandığı REACT stratejisinin genişletilmiş versiyonu olan açılama destekli REACT stratejisinin öğretim ortamlarında denenmesi önerisinde bulunup mevcut her basamağa açıklama aşaması eklenmiştir. Ancak Ültay ve Alev (2017) tarafından yapılan bu çalışmada açıklama destekli REACT'ın her aşamasında açıklama basamağının bulunması öğretmenin düz anlatıma geçmesine neden olabileceğine dikkat çekilerek açıklamaların düz anlatımdan ziyade farklı öğretim yöntem ve teknikleriyle zenginleştirilmesi gerektiği uyarısında bulunulmuştur. Açıklama aşamasında düz anlatımın kullanılması geleneksel öğretime dönüş yapılmış olur ki bu durum REACT stratejisinin temelindeki bilginin öğrenci tarafından yapılandırıldığ ifade eden yapılandırmacı öğrenmenin prensipleriyle ters düşmektedir.

Yapılan alanyazın incelemesinden hareketle öğrenci tarafından bilginin inşa edilmesine olanak tanıyan bir yapı içerisinde REACT'ın etkililiğini arttırabilmek adına Genelleştirme (Generalisation) aşamasının eklenmesinin uygun olacağı düşünülmektedir. Yapılandırmacı öğrenme kuramını benimseyen pek çok teorik çerçevede (5E öğrenme modeli, Didaktik Durum Teorisi) öğretmenle birlikte öğrencinin bilgiyi yapılandırmasına olanak tanıyan, öğrenme sürecini destekleyici, bilginin kurumsallaştırıldığı ya da değerlendirildiği aşamalar bulunmaktadır. REACT stratejisinde bu tip bir basamağın eksik olduğu düşünüldügünden bu çalışma ile REACT'a entegre edilmiş "Genelleştirme" içeren REACT+G stratejisine uygun bir öğrenme ve öğretme ortamı tasarlanmıştır.

Genelleştirme aşaması öğretmen tarafından sistematik bir şekilde tasarlanmış olup belirli öğrenmelerin gerçekleşmesi ve sürecin öğrenciyle birlikte değerlendirmesine imkân tanımaktadır. Öğretmen bu aşamada REACT'ın mevcut bütün aşamalarında grupça veya bireysel olarak verilen dikkat çekici cevapları öğrencilerin dikkatine sunar ve birlikte incelerler. Öğrencilerin aktif olduğu, verilen cevapları tekrardan sorguladığı bir tartışma ortamı oluşturulur. Eğer öğrenciler yanlış veya eksiklerini tartışma ortamında kendileri fark edemiyorsa öğretmen yönlendirici basamak sorularla keşfetmelerine fırsat tanır. Böylece her 
aşamada öğrenciler tarafından elde edilen informal bilgiler öğretmenle birlikte incelenir ve bir genellemeye varılır. Sınıfla birlikte her aşama bir karara bağlanır. Öğretmen genelleştirme aşamasında bir bakıma toparlayıcı bir rol üstlenir. Bu sayede öğrenci her aşamada ulaştığı durumların öğretmenle birlikte değerlendirmesini yapmakta ve cevaplarının doğru, yanlış veya eksik noktalarını fark etmektedirler. Sonuç olarak yapılandırmacı öğretim bakış açısına uygun bir şekilde REACT'a entegre edilen Genelleştirme aşamasıyla, REACT+G yaklaşımı oluşturulmuştur. REACT+G stratejisinin uygulamasına örnek bir öğretim planı tasarlanıp bulgularıyla birlikte sunulmuştur. Bu çalışmada, REACT stratejinde eksik olduğu düşünülen genelleştirme aşamasının eklenmesiyle birlikte REACT stratejinin daha kapsamlı bir model haline getirilebileceği öngörülmektedir.

Yürütülen bu çalışma kapsamında “Thales Paralellik İlkesi” konusunun öğretimine yönelik REACT+G öğretim stratejisine uygun bir ders planı tasarlanarak 11. Sınıf Matematik Tarihi ve Uygulamaları dersinde uygulanmıştır. “Thales Paralellik İlkesi” ve bu ilkeyle ilişkili pek çok konu ve kavramın (üçgenlerde benzerlik ve eşlik, paralellik, oran-orantı vb.) öğrenilmesinde orantısal akıl yürütme becerisinin kullanımı etkilidir. Ancak alanyazında yapılan pek çok çalışmada öğrencilerin orantısal akıl yürütme becerilerindeki eksiklerden dolayı bu konuların öğrenilmesinde zorluklar yaşandığı ya da kavram yanılgılarının ortaya çıktığı görülmektedir (Kurdal, 2016; Pakmak, 2014). İlgili alanyazında orantısal akıl yürütme becerilerini gelişiminde bağlamsal yolla yapılan öğretimin önemini gösteren çalışmalar mevcuttur (Heller, Ahlgren, Post, Behr \& Lesh, 1989). Dolayısıyla bu çalışmada 11. sınıf Matematik Tarihi ve Uygulamaları dersinde "Thales Paralellik ilkesi" konusunun bağlam temelli REACT+G öğretim stratejisi ile öğretiminin öğrencilerin orantısal akıl yürütme becerisini geliştirebileceği etkili bir öğretim ortamı sunacağı düşünülmektedir. Bu bağlamda çalışmanın amacı araştırmacı tarafından geliştirilen REACT+G yaklaşımının "Thales Paralellik İlkesi” konusunun öğretim sürecindeki yaşantıları betimlemektir.

\section{Problem Cümlesi}

REACT+G yaklaşımı ile “Thales Paralellik İlkesi” konusunun öğretim sürecinde ortaöğretim 11. Sınıf öğrencilerinin yaşantıları nelerdir? 


\section{Yöntem}

Araştırmanın Modeli

REACT+G öğretim stratejisine yönelik hazırlanan öğretim planının uygulamalarının öğretim sürecine yansımalarını incelemek amacıyla gerçekleştirilen bu çalışma nitel araştırma yöntemlerinden eylem araştırması yöntemi ile yürütülmüştür. Eylem araştırması, uygulayıcının doğrudan kendisinin ya da bir araştırmacı ile birlikte gerçekleştirdiği ve uygulama sürecine ilişkin sorunların ortaya çıkarılması ya da hâlihazırda ortaya çıkmış bir sorunu anlama ve çözmeye yönelik sistematik veri toplamayı ve analiz etmeyi içeren bir araştırma yöntemidir (Yıldırım \& Şimşek, 2016). Mertler ve Charles'e (2011) göre eylem araştırmalarının temelini eğitimcilerin eğitim problemlerine farklı bir bakış açısıyla yaklaşarak kendi eğitim uygulamalarını yeni yollarla incelemeleri oluşturmaktadır. Bu çalışmada yapılan literatür taramasıyla REACT öğretim stratejisinin uygulama sürecinde öğrenme ve öğretmenin rolü açısından çeşitli problemlerle karşılaşıldığı görülmüş olup bu durumun giderilmesi için açılama aşamasının eklenmesi gerektiği araştırmacılar tarafından belirtilmiştir (Ültay, 2012). Ancak açlklama aşamasının tek aşama olarak ya da REACT'ın her aşamasına eklenmesi bir belirsizlik oluşturmaktadır. Ayrıca açıklama aşamasının eklenmesi öğretmenin düz anlatım yöntemini kullanmasına neden olabileceğine işaret edilmektedir (Ültay, 2012). Bu durum REACT'ın temelindeki yapılandırmacı felsefeye ters düşmektedir. Dolayısıyla yürütülen bu çalışmada araştırmacı rolündeki öğretmen REACT öğretim stratejisine farklı bir bakış açısıyla yaklaşarak REACT+G öğretim stratejisini önermiştir. Ayrıca çalışmada “Thales paralellik ilkesi” konusuna yönelik REACT+G öğretim stratejisine göre bir öğretim planı geliştirilerek uygulanmış olup öğretim sürecinde oluşan bazı sıkıntıların giderilmesine yönelik öneriler sunulmuştur. Bu bakımdan çalışmanın eylem araştırması modeline uygun olduğu düşülmektedir.

\section{Çalışma Grubu}

Araştırmanın çalışma grubunu Türkiye'nin batısında yer alan bir devlet lisesindeki 11. sınıf sayısal bölümünde öğrenim gören 4 kız, 6 erkek olmak üzere toplam 10 öğrenci oluşturmaktadır. Bu çalışma kapsamında 11. sınıf düzeyinde REACT+G modeline yönelik ders planı geliştirildiğinden çalışma araştırmacılardan birinin öğretmenliğini yaptı̆̆ 11 . sınıf öğrencileri ile gerçekleştirilmiştir. Dolayısıyla yürütülen bu çalışmada katılımcılar belirlenirken kolay ulaşılabilir örnekleme yöntemi kullanılmıştır. Kolay ulaşılabilir 
örnekleme araştırmacıya kolaylık zaman ve maliyet açısından pek çok avantajlar sağlar (Miles \& Huberman, 1994; Patton, 2014). Bu çalışmada örneklemin, araştırmacı rolündeki öğretmenin bir devlet lisesinde dersini yürüttüğü 11. sınıf öğrencilerinin tamamından oluşması nedeniyle kolay ulaşılabilir örnekleme için uygun özellikler taşıdığ1 düşünülmektedir. Çalışmanın bazı aşamalarında grup çalışması yapılmıştır. Grupların matematik yazılı sınav ortalamaları baz alınarak akademik başarı bakımından birbirine benzer olması için 3-4 kişilik heterojen 3 farklı grup oluşturulmuştur. Öğrenciler grup ismine ve grup içi görev dağılımına kendileri karar vermişlerdir. Oluşturulan grupların isimleri ve gruplarda bulunan öğrenci kodları Tablo 1'de verilmiştir.

Tablo 1. Çalışma grubuna ait bazı bilgiler

\begin{tabular}{ll}
\hline Grup ismi & $\ddot{O}_{\text {ğrenci kodlar1 }}$ \\
\hline Kızlar & $\ddot{\mathrm{O}}_{1}, \ddot{\mathrm{O}}_{2}, \ddot{\mathrm{O}}_{3}, \ddot{\mathrm{O}}_{4}$ \\
Minik serçeler & $\ddot{\mathrm{O}}_{5}, \ddot{\mathrm{O}}_{6}, \ddot{\mathrm{O}}_{7}$ \\
Çıraklar & $\ddot{\mathrm{O}}_{8}, \ddot{\mathrm{O}}_{9}, \ddot{\mathrm{O}}_{10}$ \\
\hline
\end{tabular}

Veri Toplama Araçları

Araştırmada gözlem, video-ses kaydı ve öğrenci çalışma kâğıtları olmak üzere üç farklı veri toplama aracı kullanılmıştır. Veri çeşitlemesi tekniği, farklı yöntemlerle elde edilen verilerin birbirlerini teyit etmesine ve ulaşılan sonuçların geçerliliğini ve güvenilirliğini arttırmasına imkân veren bir tekniktir (Yıldırım \& Şimşek, 2016). Bu nedenle elde edilen verilerin güvenirliliğin ve geçerliliğinin arttırılması amacıyla gözlem, video-ses kaydı ve REACT $+G$ stratejisine yönelik ders planı kapsamında geliştirilen çalışma kâğıtları bir arada kullanılmıştır. Ayrıca REACT+G stratejisine yönelik ders planı kapsamında geliştirilen çalışma kâğıtları araştırmacı öğretmen tarafından oluşturulduktan sonra, iki uzman ve bir öğretmen görüşü alınarak kapsam geçerliği sağlanmıştır. Ders planının REACT+G'ye uygunluğunun değerlendirilmesi amacıyla uzman görüşü alınırken taslak ders planı ile birlikte uzmanlara REACT'ın aşamaları ve eklenmesi düşünülen Genelleme aşaması hakkında özet bilgi kataloğu verilmiştir. Uzmanların görüşleri doğrultusunda düzenlenen ders planı ve çalışma kâğıtları öğrenciler tarafından anlaşılmayacak noktaların düzeltilmesi amacıyla alanında uzman bir lise matematik öğretmeni tarafından incelenmiştir.

\section{Öğretim Materyalinin Geliştirilmesi}

Pilot uygulama çalışma grubuyla aynı sınıf seviyesinde olan ve benzer akademik başarıya sahip 26 öğrenciyle yapılmıştır. Pilot çalışma sonucunda öğretim sürecinde 
kullanılan etkinliklere bazı eklemeler ve düzeltmeler yapılmıştır. Bu eklemeler ve düzeltmeler şunlardır:

1. Çalışma kapsamında yapılan etkinliklerde öğrencilerin geliştirdikleri çözüm önerilerini, öğretmene onaylatma ihtiyacı hissettikleri gözlemlenmiştir. Bu durum yapılandırmacı öğretim yaklaşımına uygun değildir. $\mathrm{Bu}$ nedenle çalışma kâğıtlarına öğrencilerin REACT+G stratejisinin her aşamasında yer alan etkinliklere verdikleri cevapları öğretmene onaylatmamaları ve cevaplarını yazarken doğru ya da yanlış kaygısı hissetmeden yazmaları gerektiği yönünde hatırlatıcı notlar düşülmüştür. Burada amaçlanan öğrencilerin yapılandırmacı öğretim yaklaşımına uygun bir şekilde hareket etmelerini sağlayarak bilgiyi yapılandırmalarına fırsat vermektir.

2. Ders planı uygulanırken İlişkilendirme basamağında öğrencilerin bağlamla konuyu ilişkilendirdikleri gözlemlenmiştir. Fakat bu aşamada kullanılan etkinlikteki soru sayısının fazla olması, dersin gereğinden fazla uzamasına neden olmuştur. $\mathrm{Bu}$ durum uzmanlarla paylaşılarak birbirine benzer soruların çıkarılmasına ve soru sayısının azaltılmasına karar verilmiştir.

3. Tecrübe etme basamağındaki etkinlik için hazırlanan çalışma kâğıdında yer alan “Diğer grup arkadaşları sabit duran arkadaşlarının gölgesinin boyunu ölçünüz ve tabloya not ediniz" yönergesini bazı öğrencilerin ölçüm yaparken şerit cetvel yerine cetvel kullanarak yanlış pratiğe geçirdikleri gözlemlenmiştir. REACT+G stratejisinde öğrenciler deneyim yaşarken öğretmen yönlendirme yapamamaktadır. Dolayısıyla öğrencilerin yaşadıkları bu durumu engellemek amacıyla yönergeye “ölçüm yaparken şerit cetvel kullanınız." ifadesi eklenmiştir.

Yapılan düzenlemelerin sonucunda $R E A C T+G$ stratejisine göre hazırlanan ders planına ve çalışma kâğıtlarına son hali verilmiştir. Ders planı 4 ders saatini kapsayacak şekilde hazırlanmıştır. Araştırmada kullanılan çalışma kâğıtlarına bulgularda yer verilmiştir.

\section{Verilerin Analizi}

Araştırmada gözlem, video-ses kaydı ve öğrenci çalışma kâğıtlarıyla elde edilen verilerin analizinde içerik analizi yöntemi kullanılmıştır. İçerik analizi yöntemi genellikle metinlerin (mülakat dökümleri, günlükler ve dokümanlar) analizinde kullanılır (Patton, 2014).Ayrıca içerik analizi bir araştırmada elde verilerin temelindeki kavramları ayrıntılı bir 
şekilde incelenmesini ve bu kavramlar arasındaki ilişkileri ortaya çıkmasını sağlayan bir analiz yöntemidir (Miles, Huberman \& Saldana, 2014). Bu çalışmada öğretim sürecinde yapılan gözlemler, alınan video-ses kayıtları yardımıyla, çalışma kâğıdında yer alan öğrenci çözümleri detaylı bir şekilde incelendiğinden içerik analizi yöntemi kullanılmıştır.

\section{Bulgular}

$\mathrm{Bu}$ araştırma kapsamında REACT+G öğretim stratejisine göre ders planı hazırlanmıştır. Ders planın her aşamasında bir bağlam temelli durum öğrencilere çalışma kâğıtları ile sunulmuştur. Toplamda 5 çalışma kâğıdı kullanılmıştır. Bu bölümde bulgular REACT+G'nin aşamalarına göre sunulmuştur. Genelleme aşamasında bütün gruplar tarafından yapılan çözümler sınıf ortamında tartışılarak genel bir karara varılmıştır. Öğrencilerin bu tartışmalar sırasında yaşadıkları dikkat çekici bazı diyaloglar REACT+G'nin her aşamasında sunulmuştur.

\section{REACT+G'ye Göre İlişkilendirme Aşamasına Yönelik Bulgular}

Öğretim sürecinde öğrenciler ulaştıkları her çözümü doğru veya yanlış olduğunu öğretmene onaylatmadan arkadaşlarıyla tartışıp bulmaları, yapılandırmacı öğrenme sürecine uygun hareket etmeleri için öğretime başlamadan önce öğrencilerden çalışma kâğıdının en üst bölümünde yer alan uyarı mahiyetindeki Şekil 2' deki yönergeyi okumaları istenmiştir.

\section{Calısmaya başlamadan önce bu bölümü okuvunuz.}

- Bu çalışma da öğretmene düşüncelerinizin doğru veya yanlış olduğunu sormayınız.

- Öğretmenin fikirlerinden daha çok sizin fikriniz ve önerileriniz değerlidir.

- Fikirlerinizi çekinmeden kâğıdınıza yazarak ve çizimlerle ifade etmeye özen gösteriniz.

Şekil 2. Çalışma kâğıdında yer alan yönergeler

Şekil 2'de öğrencilerin ders sürecinde uyması gereken davranışları ifade eden yönergelerin öğrenciler tarafından okunması sağlandıktan sonra öğretime geçilmiştir. Öğrencilerin günlük hayatta çok sık karşılaştıkları, birçoğunun ilgi duyduğu "futbol" bağlamı konu ile ilişkilendirilmiştir. Öğrencilerin bütün uzunlukları doğrudan ölçme yöntemiyle ölçemeyeceklerini, bazı durumlarda hesaplama yaparak dolaylı ölçme yöntemlerini kullanmaları gerektiğini fark etmeleri amacıyla Şekil 3'deki problem durumu önce slâyt ile daha sonra çalışma kâğıdında sunulmuştur. 


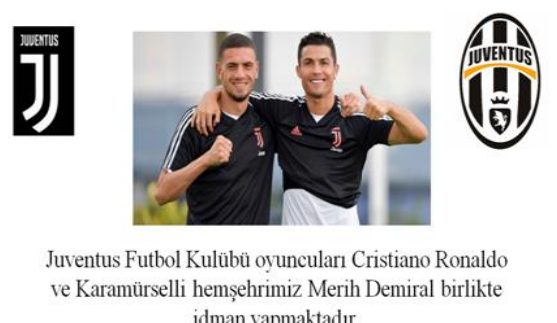

Ronaldo şut çalş̧̧ası yaparken idman yaptikları yerdekiduvarı ışması için
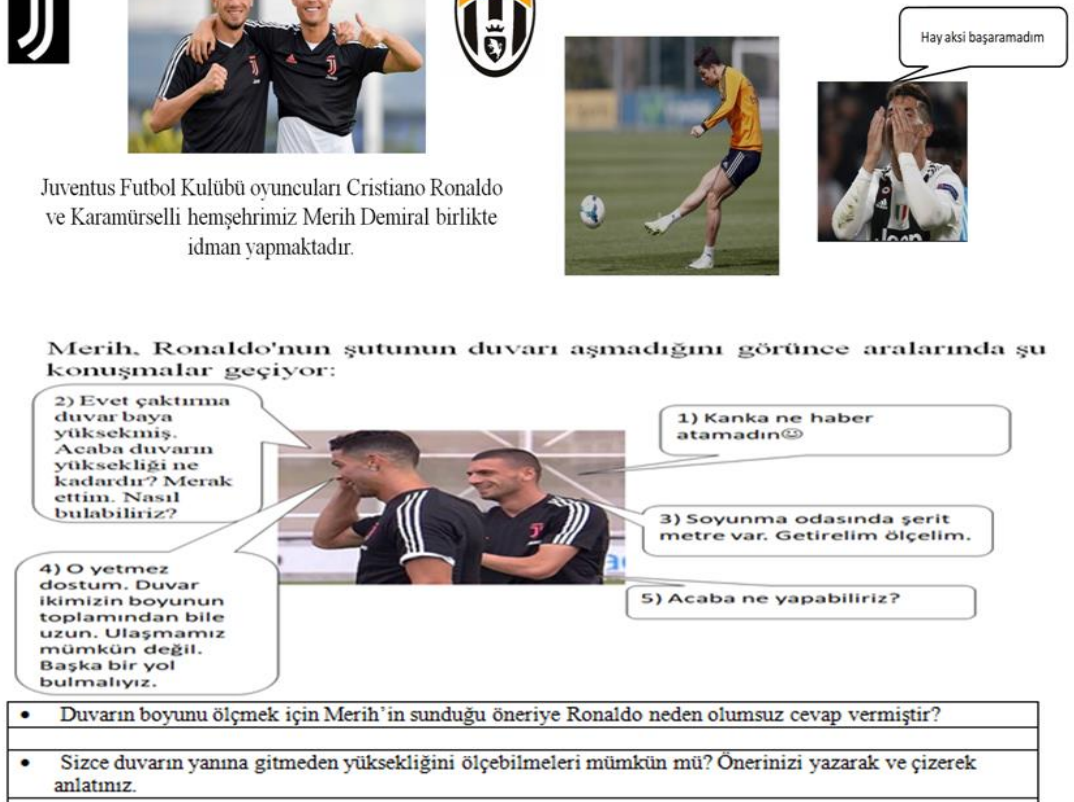

Şekil 3. İlişkilendirme basamağında sunulan problem durumu

Şekil 3'teki bağlam tasarlanırken futbolcu karakterlerin seçiminde özellikle Merih Demiral ve Ronaldo seçilmiştir. Bunun sebebi öğrencilerin futbolcu Merih Demiral'1 yaşadıkları bölge itibari ile yakından tanımaları problem durumuna dikkatlerini daha çok çekebileceğinin düşünülmesidir.

Şekil 3’te yer alan görsel öğrencilere slâytta gösterilip genel olarak sınıfta okunduktan sonra soruların bireysel cevaplanabilmesi için etkinlik her öğrenciye çalışma kâğıdı şeklinde verilmiştir. Öğrencilerin bu aşamadaki çalışma kâğıdını cevaplandırmaları 10 dakika sürmüştür. Daha sonra 2 grup 3'er, 1 grup 4 kişilik olmak üzere toplamda 3 grup oluşturulmuştur. Grup içerisinde bir sözcü, bir de yazman belirlenmesi istenerek grup içi tartışmalar için 15 dakika süre verilmiştir. Yapılan grup içi tartışmalarından sonra her gruba 5 dakika süre verilerek gruptaki sözcülerin çalışma kâğıdındaki sorulara verdikleri cevapları sınıfla paylaşmaları istenmiştir. 15 dakika gruplar arası tartışma yapılarak ilişkilendirme basamağı sonlandırılmıştır.

Öğrencilerin ilişkilendirme aşamasında kullanılan bağlam temelli problem durumuna yönelik yaptıkları çözümler incelendiğinde önceden var olan bilgileriyle bağlam temelli problem durumunu ilişkilendirdikleri görülmektedir. Nitekim öğrenci çözümlerinde yer alan bilgilerin hangi matematik konusuyla ilişkili olduğu Tablo 2'de sunulmuştur. 
Tablo 2. Öğrenci çözümlerinin ilişkili olduğu matematik konuları

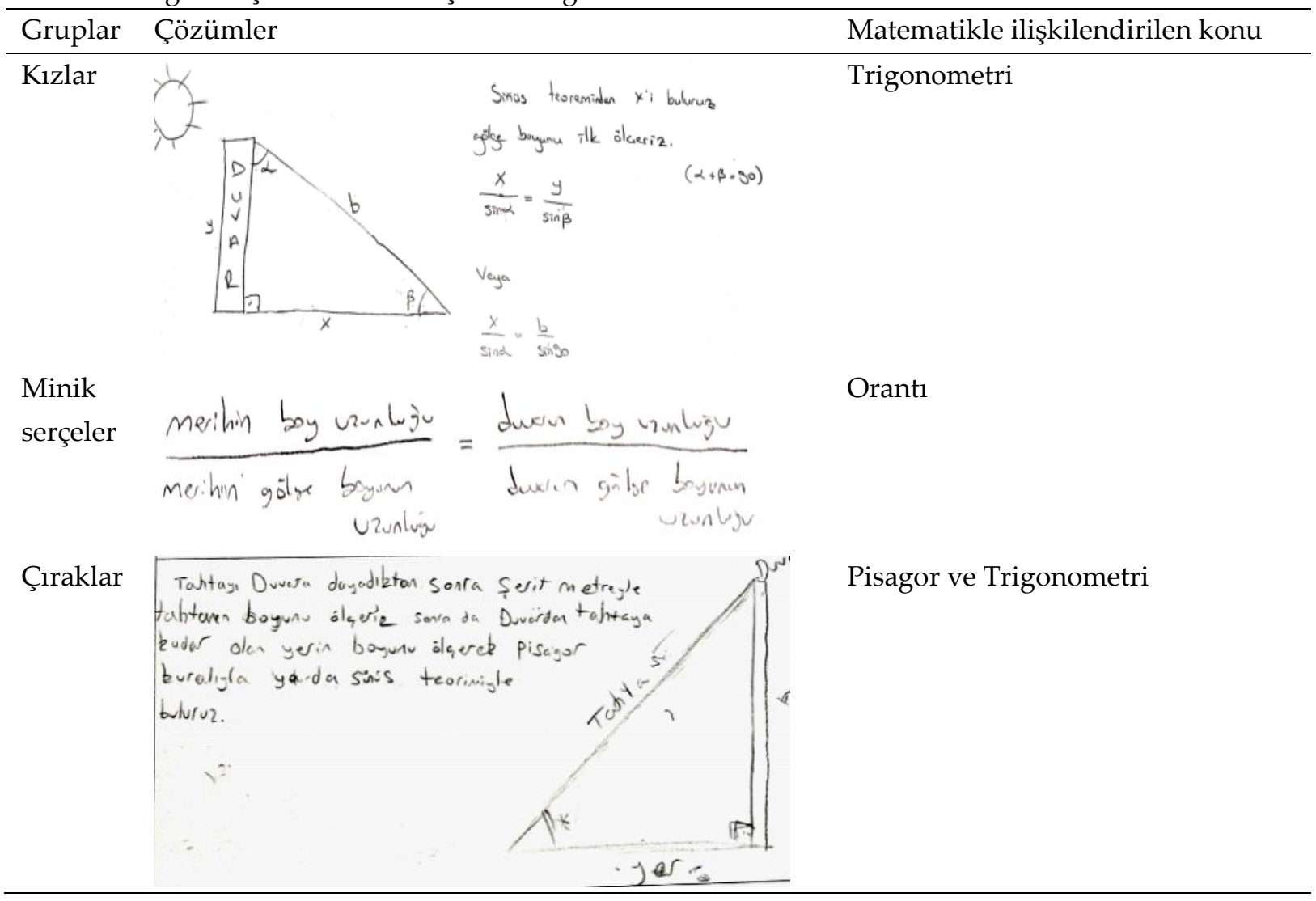

Tablo 2 incelendiğinde öğrencilerin bağlam temelli problem durumuna çözüm üretirken farklı konulardan yararlandıkları görülmektedir. Bu noktadan hareketle problem durumu ile öğrencilerin sahip oldukları ön bilgilerini ilişkilendirdikleri ve bu basamağın amacına ulaştığı söylenebilir.

REACT+G'ye Göre Tecrübe Etme Aşamasına Yönelik Bulgular

$\mathrm{Bu}$ aşamada öğrenciler sınıf dışı bir deneyim ile okul bahçesinde gölge boyu sayesinde boylarını hesaplayarak Thales teoremini yaşantısal anlamda tecrübe etmeleri amaçlanmıştır. Bu doğrultuda Şekil 5' teki çalışma kâğıdında yer alan etkinlikle küçük bir cetvel ve gölge boyu yardımıyla öğrencilerin birbirlerinin boy uzunluğunu orantı kullanarak hesaplamaları ve buldukları sonuçlar ile gerçek boy uzunluklarını karşılaştırmaları amaçlanmıştır. 


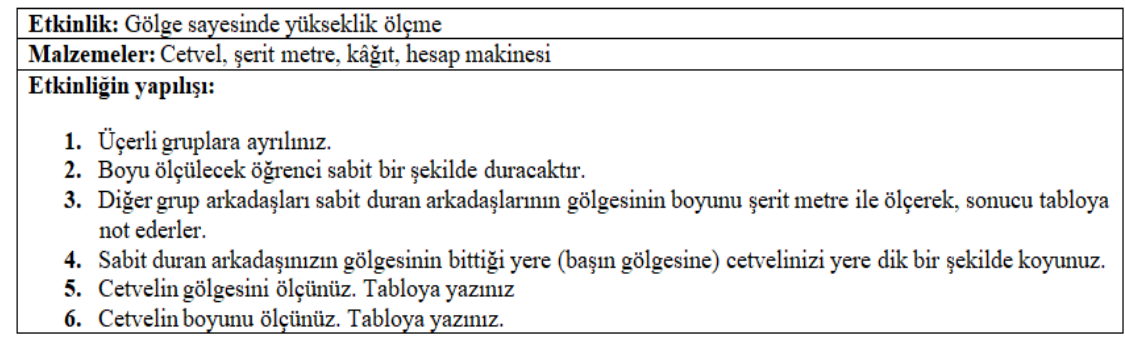

TABLO

\begin{tabular}{|l|c|c|c|}
\hline Öğrenci adı & $\begin{array}{c}\text { Öğrencinin gölge boyu } \\
(\mathbf{c m})\end{array}$ & $\begin{array}{c}\text { Cetvelin gölge } \\
\text { boyu(cm) }\end{array}$ & Cetvelin Boyu (cm) \\
\hline & & & \\
& & & \\
\hline
\end{tabular}

\begin{tabular}{|l|}
\hline - Arkadaşıızın boyunu tablodaki veriler ile hesaplayabilir misiniz? Nasıl yaparsınız çizerek ve yazarak anlatınız. \\
\hline - Arkadaşıızın boyunu direkt şerit cetvel ile ölçünüz. Elde ettiğiniz sonuç, hesapladığınız sonuç ile birbirine \\
yakın mı? \\
\hline - Bu yöntem bize ne gibi kolaylıklar sağlayabilir? \\
\hline
\end{tabular}

Şekil 4. Tecrübe etme basamağında yapılan etkinlik

Şekil 4'te verilen etkinliğin yapılması için öğrencilerden gruplarını oluşturup çalışma kâğıdındaki yönergelere göre ölçüm sonuçlarını tabloya yazmaları ve soruları cevaplamaları istenmiştir. Etkinliği yapmaları için 15 dakika verilmiştir. Etkinlikte yer alan yönergelere göre grupların okul bahçesinde yaptıkları çalışmalar Şekil 5'te görülmektedir.

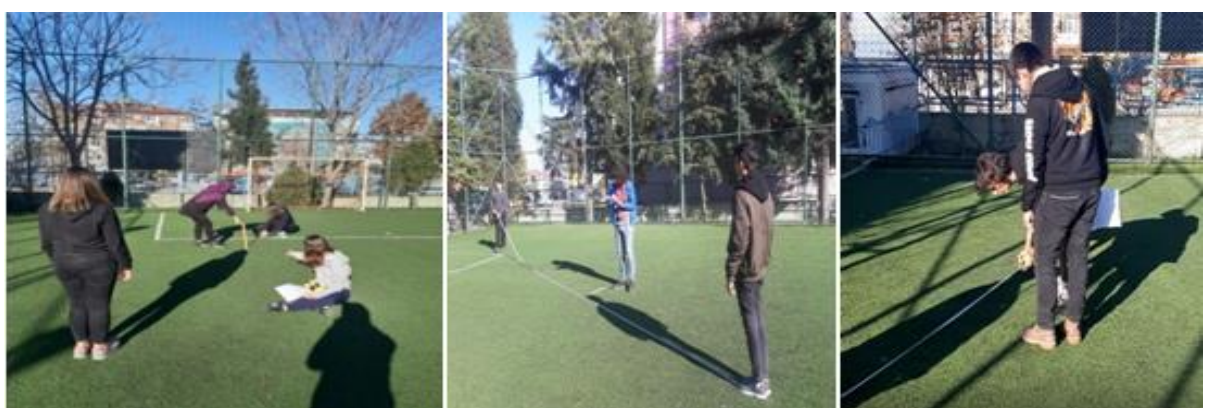

Şekil 5. Tecrübe etme basamağında grupların okul bahçesindeki çalışmaları

Şekil 5'te öğrenciler 3-4 kişilik gruplar halinde iş bölümü yaparak çalıştıkları görülmektedir. Çalışma kâğıdında yer alan yönergelere uyarak ölçümleri ve gerekli hesaplamaları yapmışlardır. Elde edilen sonuçları sınıf ortamında tartışmak için de yaklaşık 10 dakika süre verilerek tecrübe etme aşaması sonlandırılmıştır. Yapılan çözümlerde ve ses kayıtlarında dikkat çeken öğrenci ifadeleri Tablo 3’te verilmiştir. 
Tablo 3.Tecrübe etme basamağındaki öğrenci çözümleri ve ifadeleri

\begin{tabular}{|c|c|c|}
\hline Gruplar & Çözümler & Dikkat çeken öğrenci ifadeleri \\
\hline Kizlar & 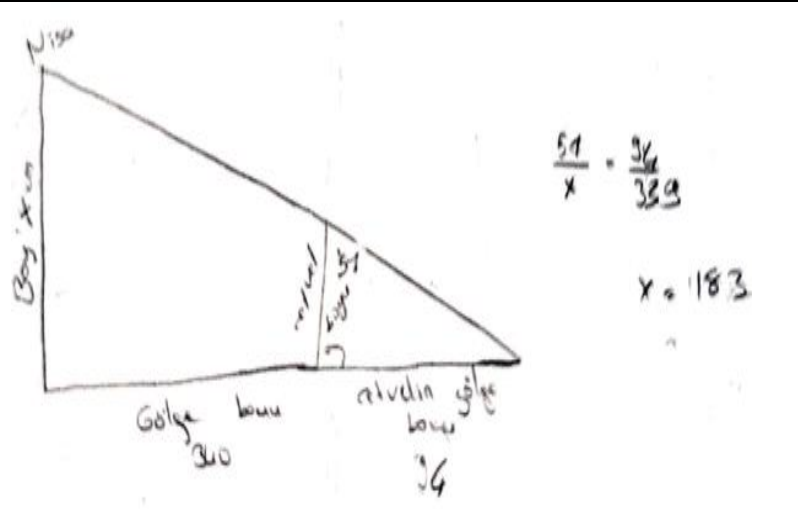 & $\begin{array}{l}\text { Ö9: "Abdulkadir'in gölge boyunu } \\
\text { ve cetvelin boyunu oranlarsak..." }\end{array}$ \\
\hline $\begin{array}{l}\text { Minik } \\
\text { serçeler }\end{array}$ & 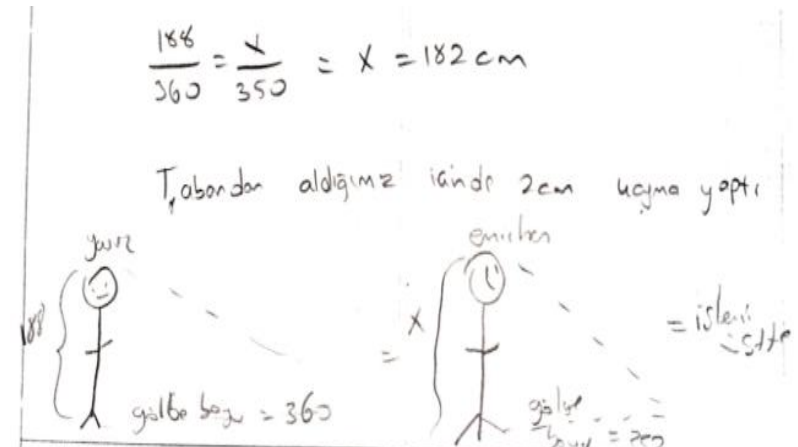 & $\begin{array}{l}\ddot{O}_{2:} \text { "Şimdi bu ölçülerle bir üçgen } \\
\text { çizelim." }\end{array}$ \\
\hline Çıraklar & 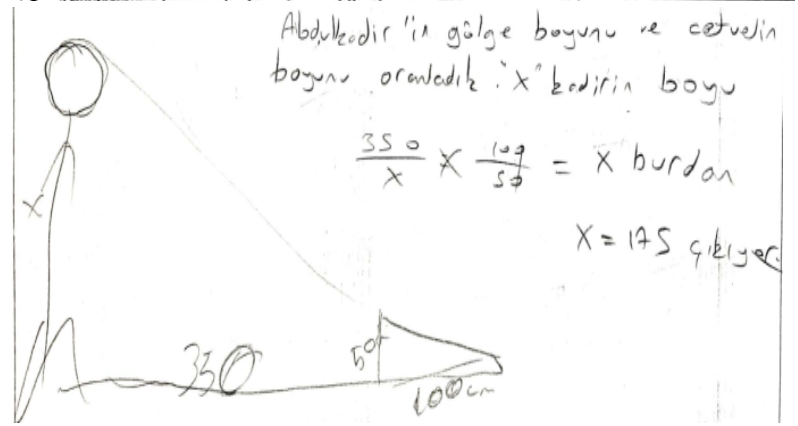 & $\begin{array}{l}\text { Ö}_{5} \text { "Cetvelin ve gölgesinin boyuna } \\
\text { gerek yok bence. Cetvel yerine } \\
\text { kendi boyum ve gölgemin } \\
\text { uzunluğundan yararlanabiliriz." }\end{array}$ \\
\hline
\end{tabular}

Tablo 3 incelendiğinde öğrenciler etkinlikte verilen yönergeler doğrultusunda Thales teoreminin temelini oluşturan orantıyı kurdukları ve bunu yaparken kendilerine özgü yöntemlerde kullandıkları görülmektedir. Nitekim minik serçeler grubunun çözümlerini yaparken aslında cetvele ve gölgesine ihtiyaç olmadığını, bunun yerine açıklamayı yapan öğrenci kendi boyunun ve gölgesinin uzunluğundan faydalanabileceğini belirtmesi dikkat çekici bir bulgudur. Dolayısıyla bu aşamanın temeli olan öğrencinin öğrenme sürecinde aktif olması ve ilk elden deneyim yaşamasının sağlandı̆̆ı söylenebilir. Ayrıca bu aşamada öğrencilerin diğer aşamalara göre daha istekli oldukları gözlemlenmiştir. Öğrenciler sınıf dışı bir ortamda arkadaşlarıyla birlikte ölçümler yapması, sonuçlara ulaşmaya çalışması, elde ettiği ölçümlerin yakın çıktığını fark etmesi, bu süreci diğer aşamalara göre daha zevkli ve eğlenceli bir hale getirdiği söylenebilir. 


\title{
REACT+G'ye Göre Uygulama Aşamasina Yönelik Bulgular
}

Uygulama aşamasında öğrencilere 10 dakika süre tanınmıştır. $\mathrm{Bu}$ süre zarfında öğrencilerden bireysel olarak çalışma kâğıdındaki Şekil 6'da verilen bağlam temelli problem durumunu cevaplamaları istenmiştir.

\begin{abstract}
Ayşe yanında duran ağacin uzunluğunu merak etmektedir. Ağacın boyunu direkt ölçemeyeceği için gölge boyunu ölçmenin uygun olacağını düşünmüiştür. Ağacın gölge boyunu $120 \mathrm{~cm}$, kendi gölge boyunu ise $60 \mathrm{~cm}$ olarak ölçüyor. Ayşe boyunun $150 \mathrm{~cm}$ olduğunu bildiğine göre elindeki verilerle ağacın boyunu nasıl bulabilir? Çizerek hesaplayınız.
\end{abstract}

Şekil 6. Uygulama aşamasında sunulan problem durumu

Problem durumuna yönelik bireysel çözümlerini sınıf ortamında paylaşmak isteyen öğrencilere söz hakkı verilmiştir. Daha sonra işbirliği aşamasına hazırlık için öğrencilere grup olarak araştırmaları gereken konuyla ilişkili bağlam temelli yukarıdaki problem verilmiştir. Bir sonraki ders için bu problemin çözümüne yönelik araştırma yapmaları istenerek uygulama basamağı sonlandırılmıştır.

Öğrencilerin uygulama aşamasında kullanılan bağlam temelli problem durumuna yönelik yaptıkları bireysel çözümler incelendiğinde bütün öğrencilerin doğru çözüme ulaştıkları görülmüştür. Bu nedenle her gruptan birer öğrenci belirlenmiştir. Bu öğrencilerin problem durumuna yönelik yaptıkları çözümler ve bu çözümlere ait öğrenci çizimleri Tablo $4^{\prime}$ te verilmiştir.

Tablo 4.Uygulama Basamağındaki Öğrenci Çözümleri

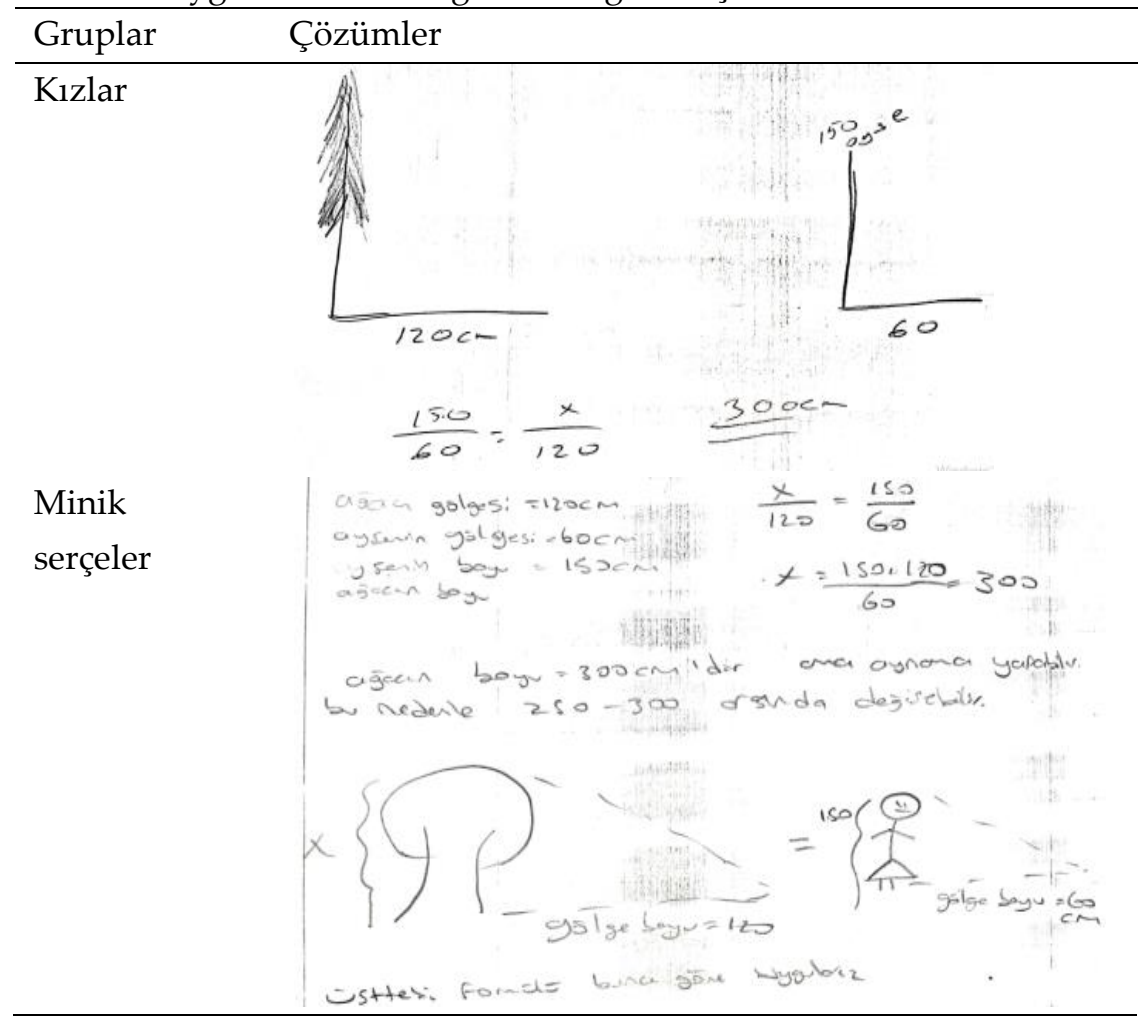


Tablo 4 (devamı). Uygulama basamağındaki öğrenci çözümleri

Gruplar Çraklar
\[ \frac{150}{60} \times \frac{x}{120}=60 x=\frac{150.12}{602} \]
$x=300$

Tablo 4 incelendiğinde öğrencilerin uygulama basamağındaki problem durumuna çözüm üretmek adına tecrübe basamağında edindikleri deneyimleri doğru bir şekilde kullandıkları görülmektedir. Problem durumunu anlamak için tecrübe etme basamağında olduğu gibi şekilsel çizimler yapmaları bilgiyi özümsediklerini göstermektedir. Dolayısıyla bu aşama ile öğrencilerin herhangi bir bilgiyi ezberlemenin aksine günlük yaşamla ilişkili problem durumuna yönelik edinilen tecrübelerle bilginin daha da içselleştirilmesinin sağlandığı söylenebilir.

\section{REACT+G'ye Göre İşbirliği Aşamasına Yönelik Bulgular}

Uygulama aşaması bittiğinde öğrencilere grup olarak araştırma yapmaları gereken Şekil 7'deki bağlam temelli problem durumu verilmiştir.

\footnotetext{
Havanın güneşli olmadığı bir günde bayrak direğinin boyunu bulmak istiyoruz. Gölge olmadığından bu çalışmayı yapamıyoruz. Ama elimizde bir ayna var. Bayrak direğinin uzunluğunu bu ayna ile ölçmemiz mümkün müdür? Yazarak çizerek anlatınız.
}

Şekil 7. İşbirliği aşamasında sunulan problem durumu

Şekil 7'deki problem durumunun işbirliği aşamasına geçilmeden önce verilmesi öğrencilerin derse ön hazırlık yaparak gelmelerini sağlamıştır. Gruplar ürettikleri çözümleri grup sözcüleri aracılığıyla sınıf ortamında sunmuşlardır. Bu aşamada öğrenciler sosyal çevresiyle iletişim kurarak bilgi paylaşımında bulunmuşlardır. Dolayısıyla işbirliği aşamasında öğrencilerin araştırma yaparak öğrenmeleri ve iletişim becerilerini gelişimini sağlamak hedeflenmiştir. İşbirliği aşaması yaklaşık olarak 15 dakika sürmüştür. Dersin kalan süresinde transfer aşamasına geçilmiştir. İşbirliği aşamasında kullanılan Şekil 7'deki bağlam temelli soruya ilişkin her grubun ürettiği çözümler ve bu çözümlerin grup sözcüleri tarafından sınıf ortamında sunulurken sınıf ortamında yaşanan diyaloglar Tablo 5'te verilmiştir. 
Tablo 5. İşbirliği aşamasındaki problem durumuna ilişkin grup çözümleri

\begin{tabular}{|c|c|c|}
\hline Gruplar & Çözümler & Sınıf ortamında yaşanan diyaloglar \\
\hline Kizlar & $\frac{x}{x \sqrt{2}}=\frac{6}{b \sqrt{2}}$ & $\begin{array}{l}\ddot{O}_{5}: \text { "Direğin boyuyla aynı mesafede ölçtün } \\
\text { ya direğin boyunu nereden biliyorsun?" } \\
\text { S: "İşte bulacaksın denklemden eşitledik ya" } \\
\text { Ös: "Boyunu bilmiyoruz ki aynayı nereye } \\
\text { koyacağını nerden biliyorsun?" } \\
\text { S: "İşte aynada tam görünecek şekilde yere } \\
\text { kadar koyuyorum tam çıkıyor boyu anladın } \\
\text { mı?" } \\
\ddot{O}_{5}: \text { "Denemeden bilemeyiz?" }\end{array}$ \\
\hline $\begin{array}{l}\text { Minik } \\
\text { serçeler }\end{array}$ & 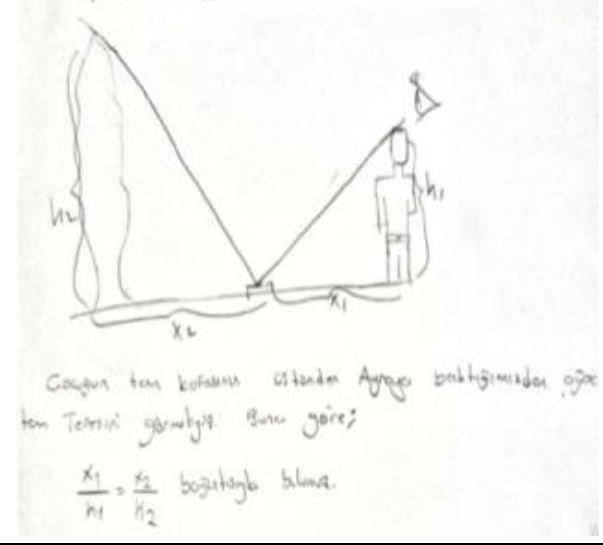 & 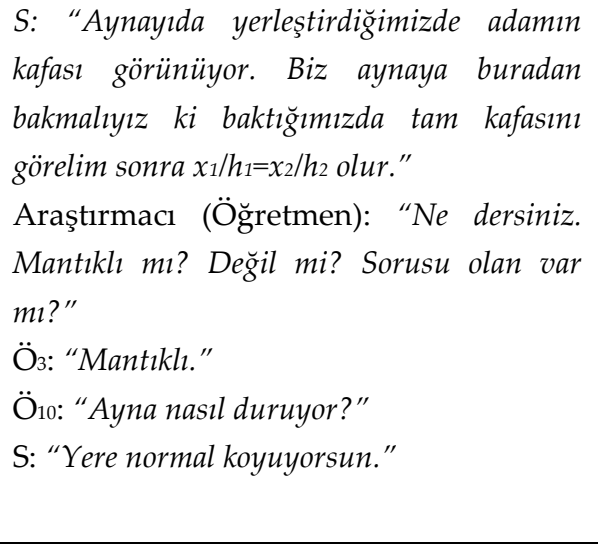 \\
\hline Çıraklar & 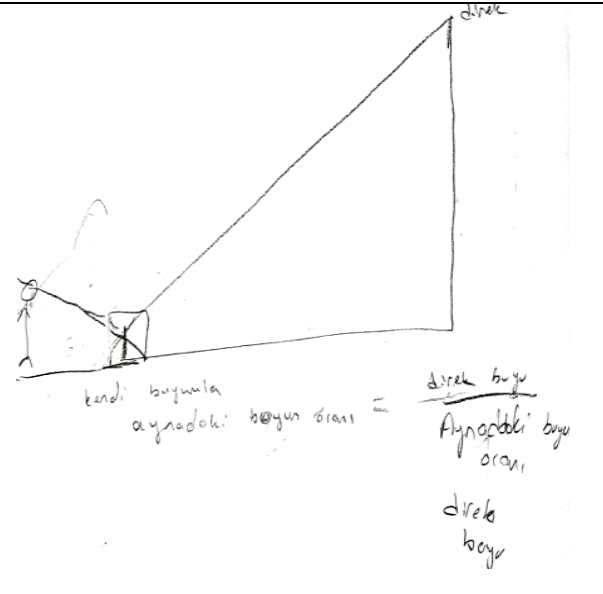 & $\begin{array}{l}\text { Sözcü: "Aynadaki görüntüyle boyunu } \\
\text { oranlarız" } \\
\text { Ös: "Ayna dik mi?" } \\
\text { S: "Evet" } \\
\text { Ös: "Aynadaki görüntü bayrak direğinin kat } \\
\text { kat küçü̆g̈ü nasıl oranlayacaksın ki?" } \\
\text { A: "Yani diğer çözümlerdeki gibi bir sistem } \\
\text { var mı?" } \\
\text { S: "Sistem yok fikir var." } \\
\text { Ös: "Ben buldum direk yerine kendisini } \\
\text { koysun oraya kendi aynada ne kadar çıkıyor } \\
\text { onunla kendi boyu arasında kaç kat fark var. } \\
\text { Aynısını direk yapıp aynada çıkan } \\
\text { görüntüyü o kadar şeyle çarpsin." }\end{array}$ \\
\hline
\end{tabular}

İlk olarak Kızlar grubu çözümünü sunmuş Tablo 5'te yapılan çözüm yolu üzerine öğrenciler fikir paylaşımı yaparak sözcüye açıklamalarını istedikleri noktalara yönelik sorular sorarak tartışma ortamı oluşturulmuştur. Diyaloglardan da anlaşıldığı üzere kızlar grubu sözcüsü bazı noktalara cevap verememiştir. Çözümleri çizim ve teknik olarak doğru olmasına rağmen direk uzunluğu ve aynanın direğe uzunluğunun nasıl eşit olacağı noktasında arkadaşlarının sorusuna tatmin edici cevap veremedikleri görülmektedir. Bu noktada öğretmenin doğru veya yanlış olduğuna dair müdahalesi olmamıştır. Amaçlanan öğrencilerin bir tartışma ortamında fikirlerini ifade etmelerine ve savunmalarına izin vermektir. Daha sonra minik serçeler grubunun çözümlerini Tablo 5'teki gibi anlatmalarına ve diğer öğrencilerin de çözümü sorgulamalarına izin verilmiştir. Minik serçeler grubunun 
doğru çözümü ve sözcünün ayrıntılı ve formülleştirerek anlatımı öğrencilere mantıklı gelmiştir. Son olarak Çıraklar grubunun çözümü ile ilgili ifadelere bakıldığında grup sözcüsü arkadaşlarını ikna edememiştir. Fakat arkadaşları çözüme katkı sağlamak adına fikirlerini dile getirmişlerdir. Öğrenciler böylelikle bu aşamada kendi gruplarının ve diğer grupların farklı çözüm yollarını inceleyerek doğruyu işbirliği içerisinde keşfetmelerine olanak sağlanmıştır.

\section{REACT+G'ye Göre Transfer Etme Aşamasına Yönelik Bulgular}

Transfer aşamasında öğrencinin öğretim sürecinde karşılaştığ durumlarından farklı ancak konuyla ilişkili yeni bir bağlam temelli problem durumu ile karşılaşması sağlanmalıdır. Öğrenciden beklenilen ise öğretim sürecinde edindiği bilgileri karşılaştı̆̆ı yeni bağlam temelli problem durumuna aktarmasıdır. Bu çalışmanın Transfer aşamasından önceki aşamalarında ölçme aletleriyle doğrudan ölçülemeyecek uzunluktaki cisimlerin boylarının ölçülmesinde Thales Paralellik ilkesinin kullanımıyla ilgili problem durumları öğrencilere sunulmuştur. Transfer etme aşamasında diğer aşamalardan farklı olarak, daha önceden karşılaşmadıkları çok uzak mesafelerin ölçülmesinde Thales paralellik ilkesinin kullanılmasını gerektiren Şekil 8'deki bağlam temelli problem durumu öğrencilere sunulmuştur.

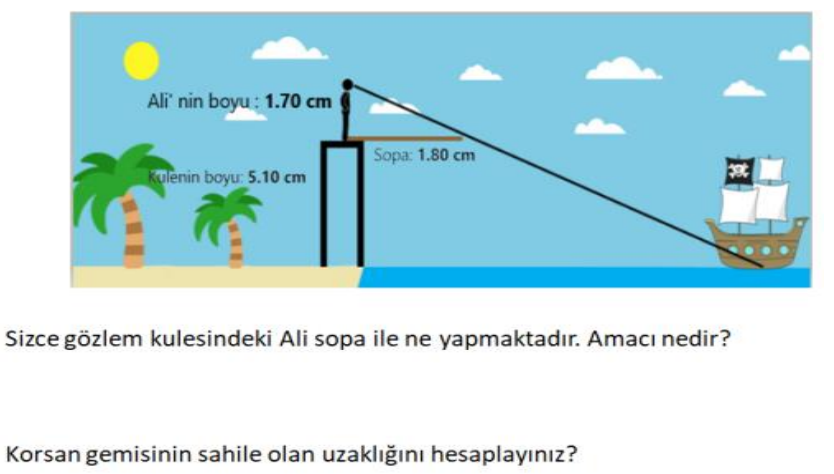

Şekil 8. Transfer aşamasında sunulan problem durumu

Şekil 8'de verilen problem durumunun ilk kısımda gözlem kulesindeki kişinin sopa ile ne yaptığı sorulmuştur. Burada öğrencinin problem durumunu anlaması, önceki aşamalarda öğrendiği bilgileri mevcut duruma aktararak olay üzerine bir yorum yapması amaçlanmıştır. İkici soruda ise öğrencinin Thales Paralellik ilkesi hakkında bildiklerini yeni problem durumuna aktarması beklenmiştir. 
Öğrencilere bireysel olarak çalışma kâğıdında verilen Şekil 8'deki problem durumuna yönelik çözümler üretmeleri için 10 dakika süre tanınmıştır. Daha sonra 5 dakika grup arkadaşlarıyla çözüm önerilerini paylaşmaları istenmiştir. Kalan 10 dakikada ise çözüm önerilerini sınıf ortamında paylaşmak isteyen öğrenciler sunumlarını yaptıktan sonra transfer aşaması sonlandırılmıştır.

Transfer aşamasında kullanılan bağlam temelli problem durumuna yönelik grup sözcülerinin sunduğu çözümler incelendiğinde bütün grupların doğru çözüme ulaştıkları görülmüştür. Bu nedenle her grubun problem durumuna yönelik sundukları çözüm yolları Tablo 6'da verilmiştir.

Tablo 6. Transfer etme basamağındaki öğrenci çözümleri

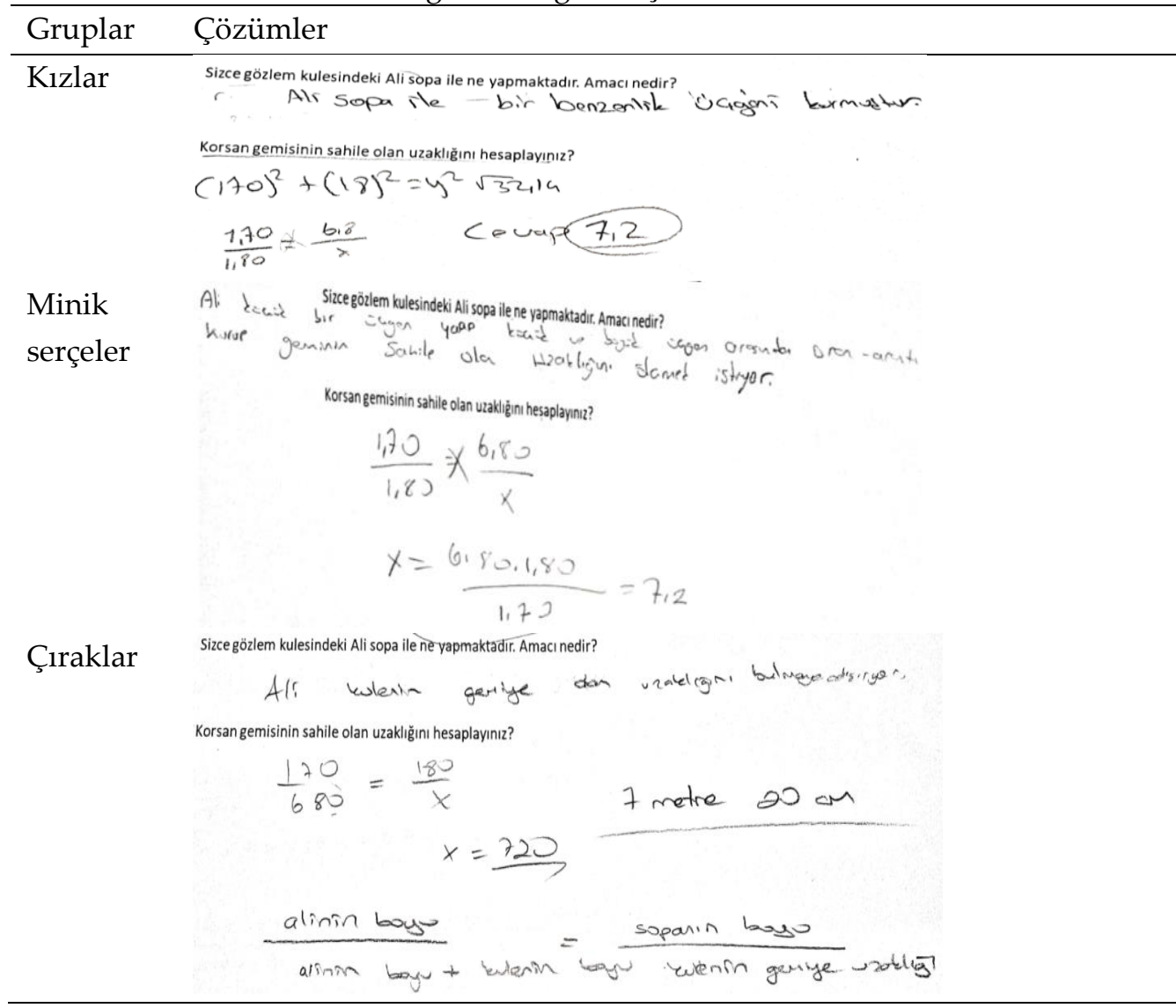

Tablo 6'da grupların çözümleri incelendiğinde öğrencilerin bilgiyi bir bağlamdan karşılaşmadıkları diğer bağlama transfer edebildikleri görülmektedir. Bu sayede öğrencilerin bilgiyi derinleştirebilme imkânı elde ettikleri geliştirdikleri çözümlerden anlaşılmaktadır. 
REACT+G'ye göre Genelleştirme Aşamasına Yönelik Bulgular

$\mathrm{Bu}$ aşamada öğretmen belirli öğrenmelerin gerçekleşmesi ve sürecin öğrenciyle birlikte değerlendirmesini yapılmıştır. REACT'ın her bir aşamasında grupların geliştirdiği çözüm önerileri öğretmen tarafından tahtaya yansıtılmıştır. Çözümler sınıfla beraber incelenerek eleştirel bir bakış açısı sonunda ortak bir karar oluşturulmaya çalışılmıştır. Daha sonra öğretmen eksik veya yanlış olan noktalar var ise öğrencilerin doğruyu kendilerinin keşfetmeleri adına yönlendirici, basamak sorular sormuştur. Bu esnada öğrencilerden düzeltmeleri ve açıklamaları not almaları istenmiştir. Öğretmen, sınıf tarafından genel olarak doğru kabul edilen çözümle ilgili bir adlandırma yapalım önerisi sunmuştur. Öğrencilerle birlikte elde edilen doğru çözümlere isimlendirme yapılmıştır. Daha sonra öğretmen elde ettikleri bu bilginin “Thales Teoremi" olduğunu öğrencilerle paylaşmıştır. "Thales Teoremi” hakkında ayrıntılı bir şekilde açıklamalar yaptıktan sonra teoremin nasıl bulduğu ile ilgili bilgi paylaşım yapılarak 40 dakikalık genelleştirme aşaması sonlandırılmıştır.

Genelleştirme basamağında ilk olarak ilişkilendirme aşamasındaki grupların bağlam temelli probleme yönelik yaptıkları çözümler sınıfça öğretmenle birlikte incelenmiştir. Bu incelemeler yapılırken yaşanan diyaloglar Tablo 7'de verilmiştir.

Tablo 7. İlişkilendirme aşamasındaki grup çözümlerinin genelleştirilmesi

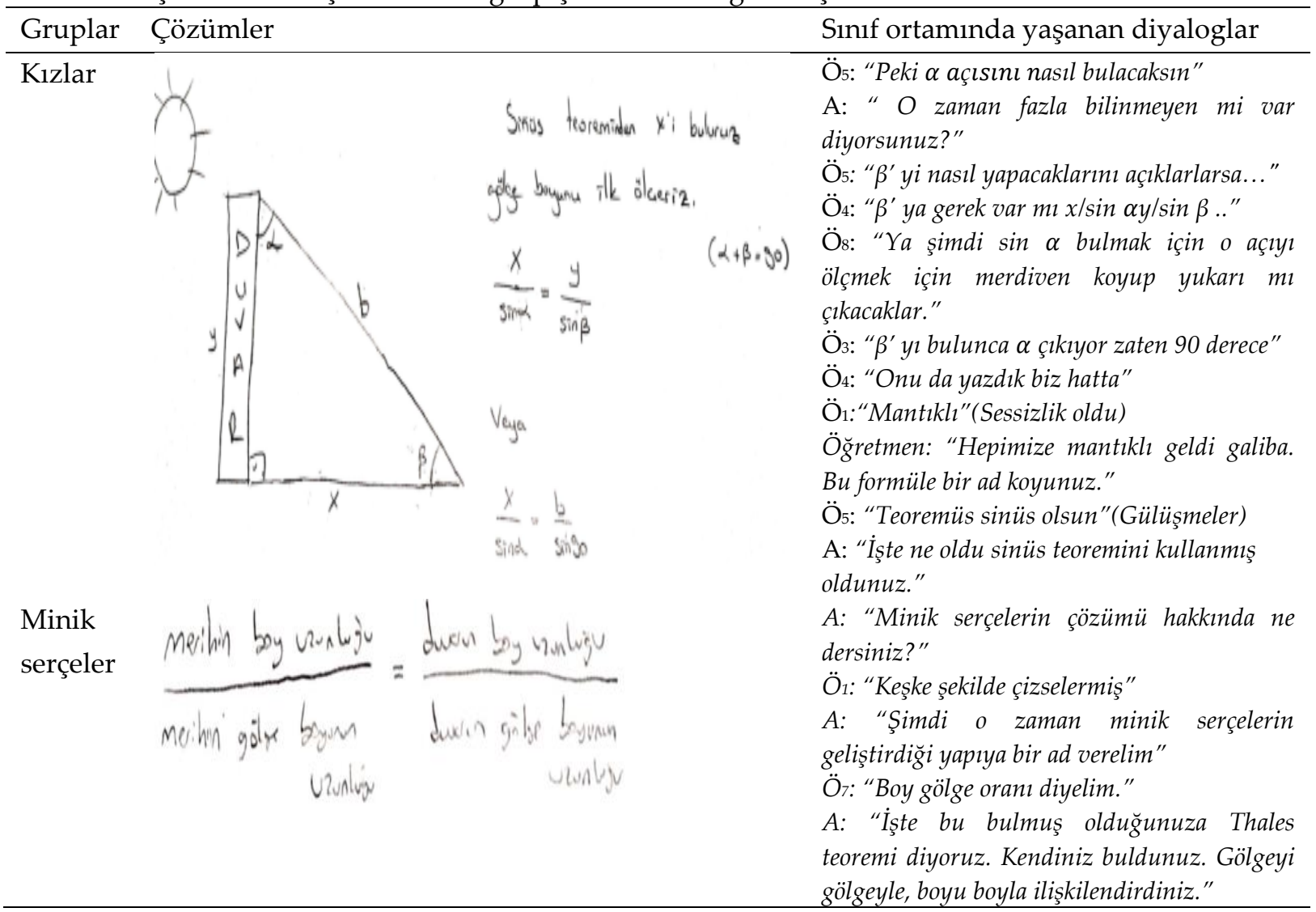


Tablo 7 (devamı).İlişkilendirme Aşamasındaki Grup Çözümlerinin Genelleştirilmesi

\begin{tabular}{|c|c|c|}
\hline Gruplar & Çözümler & Sınıf ortamında yaşanan diyaloglar \\
\hline Çıraklar & 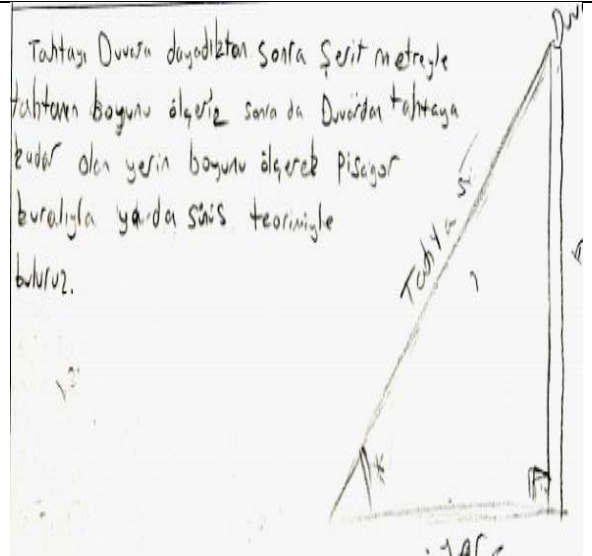 & 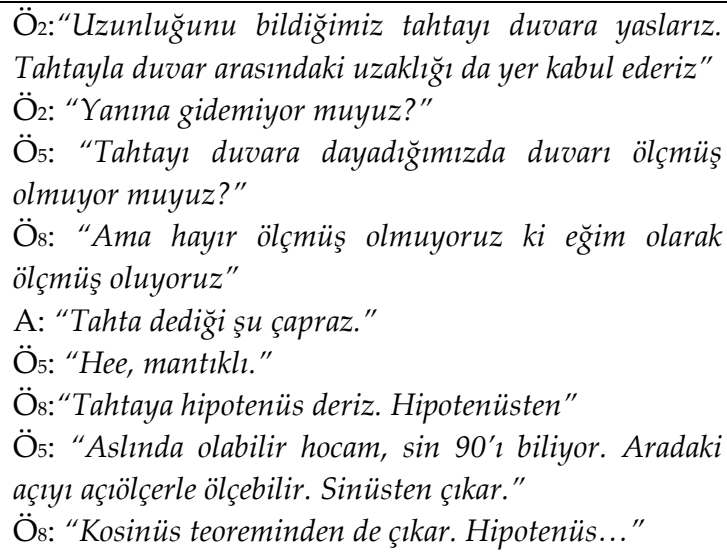 \\
\hline
\end{tabular}

Tablo 7'de görüldüğü üzere öğrencilerin ilişkilendirme basamağında elde edilen çözümler üzerine eleştirel bir bakış içerisinde süreci sorguladıkları görülmektedir. Öğrencilerin bir tartışma ortamı içerisinde kendi gruplarının fikirlerini savunan argümanlar ürettikleri ve diğer gruplarında çözümü anlamak adına sorgulama yaptıkları ifadelerine yansımaktadır. Süreç içerisinde gruplar ilişkilendirme basamağındaki çözümleri özümseyip, düşünceler hakkında ortak kararlar alınmıştır. Öğretmen öğrencilerin elde ettikleri formülü sahiplenmeleri adına bir adlandırma yapmalarını istemiştir. Öğrenciler kendi adlandırmalarını yaptıktan sonra öğretmen Thales teoreminden bahsederek onların ürettikleri formüllerin bu teoremle ilişkili olduğunu belirterek ilişkilendirme basamağının genelleştirilmesi sürecini bitirilmiştir.

Genelleştirme basamağında ikinci olarak tecrübe etme aşamasındaki grupların elde ettikleri çözümler öğretmenle birlikte incelenmiştir. Yapılan çözümlemelerden Minik serçeler ve Çıraklar gruplarının ölçümlerinin ve çözüm tekniklerinin doğru olduğu, kızlar grubunun ise ölçümlerinin yanlış ancak tekniklerinin doğru olduğu sınıf ortamında tartışılarak görülmüştür. Bu tartışma ortamındaki öğrenci diyaloglarının bir kısmı şu şeklidedir:

A: "Kızlar grubunda sonuç $183 \mathrm{~cm}$ çıkmış. Nisa'nın gerçek boyu $168 \mathrm{~cm}$ sizce sonuç yakın mı?"

Ö6:"Hayır"

A:"Peki sizin ölçümünüzden elde edilenle arkadaşınızın gerçek boyu arasındaki fark kaç cm çıkmıştı?" (Diğer gruplara yöneltilen soru)
Ö6:"2 $\mathrm{cm} "$
Ö:" $5 \mathrm{~cm}$ "

A:"Peki bu söylediğiniz fark miktarları önemli mi sizce?"

Ös:"Hayır"

A:"Peki Kızlar grubunda fark kaç? $15 \mathrm{~cm} . "$ 
Ö:"“Olsun ama bizim çözüm yolumuz doğru."

A:"Nasıl çözdünüz?"

Ö:" "Oran-orantı"

A: "Kendiniz bir ad koysanız ne derdiniz kullandığını formüle?"

Ös: "Serçe teoremi olsun adr." (Gülü̧̈meler)

Diyaloglardan da anlaşıldığı üzere öğretmen, kızlar grubunun çözümünü sorgulatmaya yönelik sorduğu sorularla grupların çözümlerini birbirleriyle karşılaştırmalarına teşvik etmiştir. Böylece diğer gruplar kızlar grubunun ölçümünde yakın sonuç elde edemediklerini fark etmelerini sağlamıştır. Ancak öğrenciler ölçümlerde farklılık olsa da çözümün teknik olarak doğru olduğunu da belirtmeleri çözümü tam anlamıla incelediklerini göstermektedir. Bu anlamda öğrenciler tarafından Tecrübe etme basamağının genelleştirme sürecinin benimsendiği söylenebilir.

Genelleştirme basamağında üçüncü olarak, uygulama aşamasındaki bireysel çözümler tahtaya sırası ile yansıtılarak öğretmenle birlikte incelenmiştir. Öğrencilerin tamamının doğru çözüme ulaştıkları gözlemlenmiştir. Bu durumun oluşmasında tecrübe etme basamağının verimli geçmesinden kaynaklandığı söylenebilir.

Genelleştirme basamağında dördüncü olarak işbirliği basamağındaki grup çözümleri tahtaya yansıtılarak öğretmenle birlikte incelenmiştir. İşbirliği aşaması uygulanırken sınıf ortamında hali hazırda grup çözümleri paylaşılmıştır. Buna ilaveten çözümlerinde eksiklik gören veya değişiklik öneren kızlar ve çıraklar grubu sınıf ortamında tekrar fikirlerini Tablo 8'de yer alan ifadelere göre paylaşmışlardır.

Tablo 8. İşbirliğgi aşamasının genelleştirilmesinde yaşanan diyaloglar

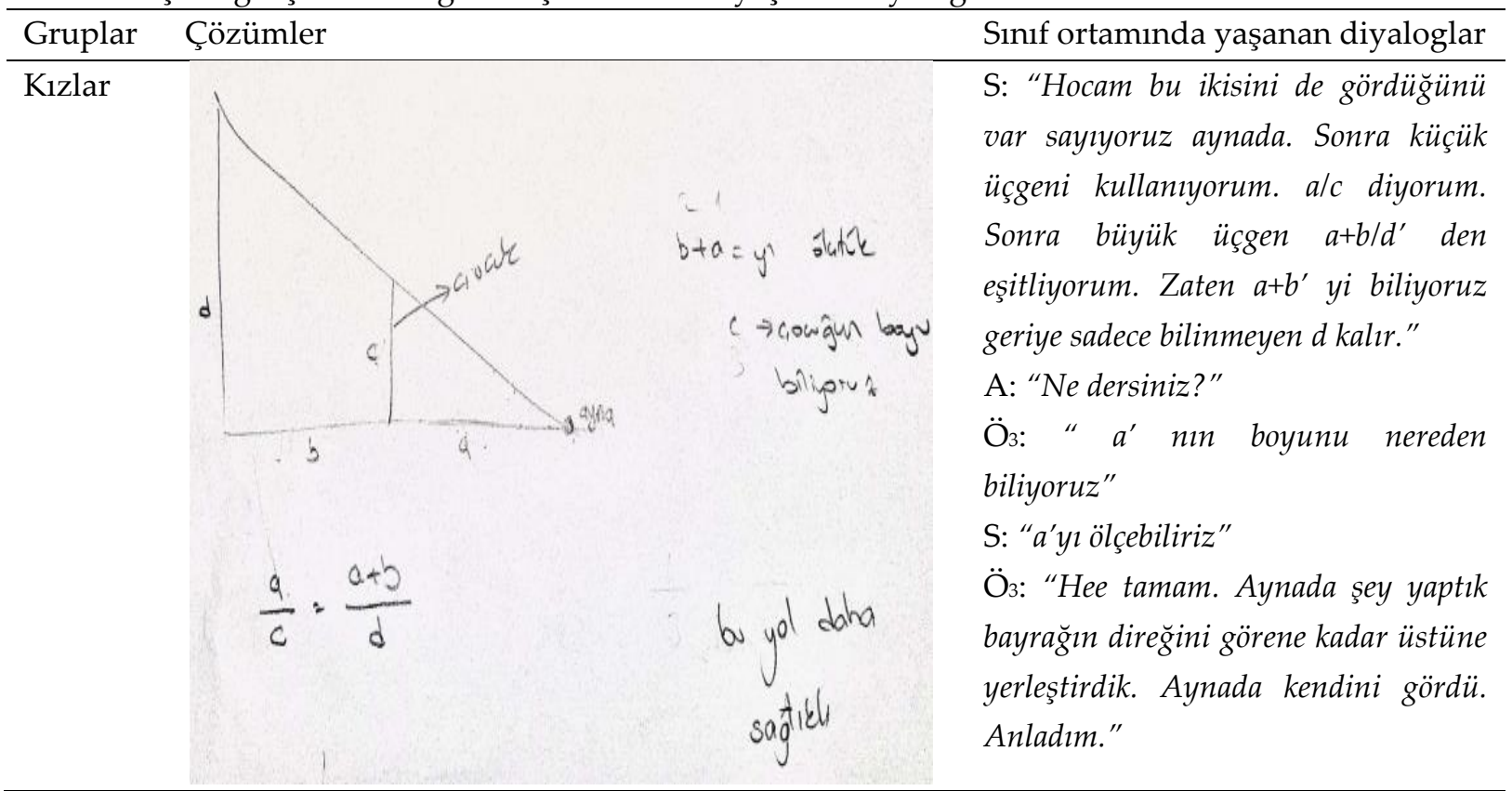


Tablo 8 (devamı). İşbirliği aşamasının genelleştirilmesinde yaşanan diyaloglar

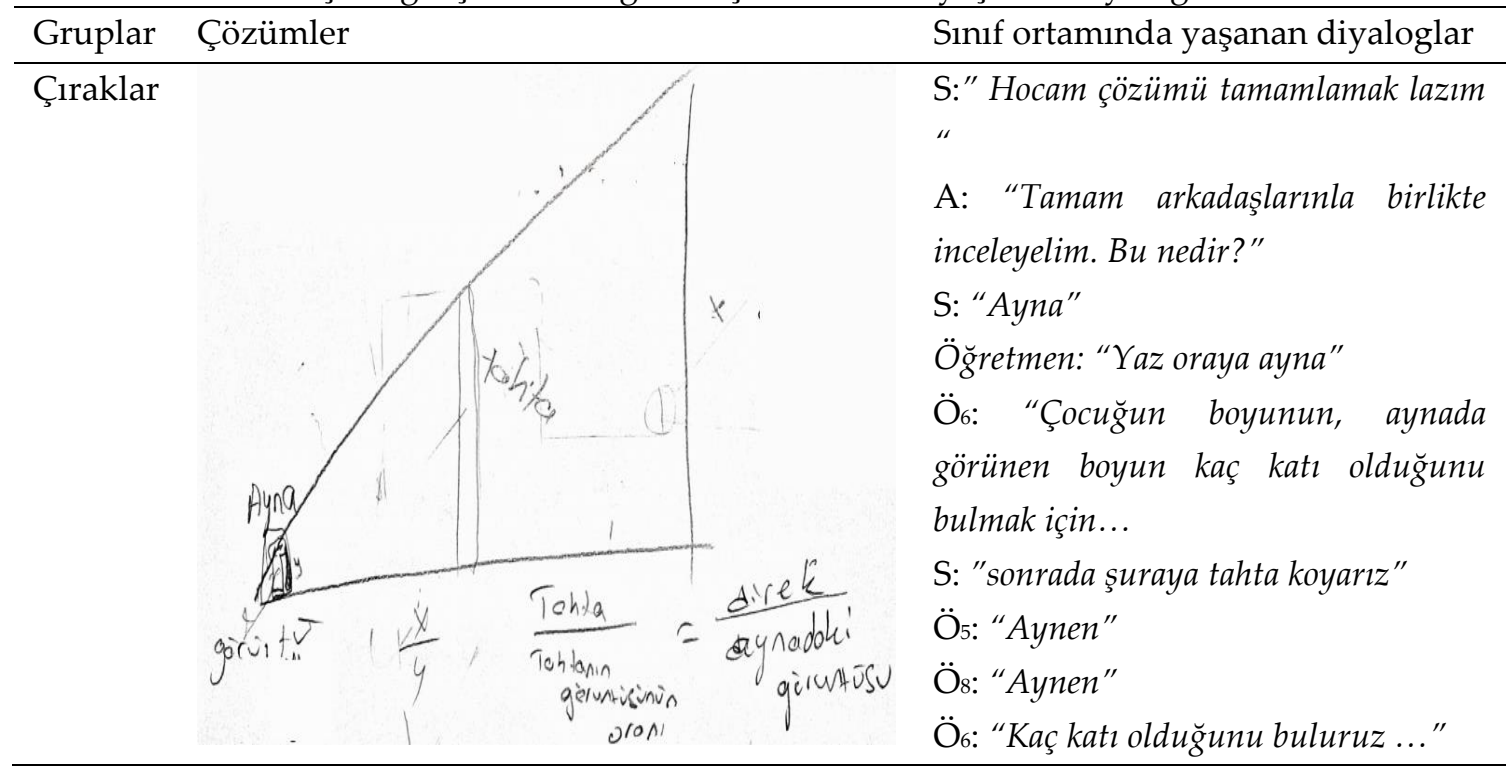

Tablo 8 incelediğinde öğrencilerin işbirliği aşamasındaki çözümlerini sorguladıkları ve içselleştirdikleri (kızlar grubunun "bu yol daha sağlıklı" notundan) anlaşılmaktadır. İşbirliği aşamasında grupların sınıf ortamında çözümlerini paylaşmalarının öğrencilerin cevaplarını kontrol etmelerine, eksik noktaları tespit etmelerine, yeni çözüm yolları geliştirmelerine ve birlikte öğrenmelerine olumlu yönde katkı sağladığı görülmüştür. Bu sayede öğrenciler işbirliği basamağının genelleştirilmesine dair eski çizimleri ve arkadaşlarının geliştirdiği yeni ve farklı çözüm yollarını sorgulayarak, anlayarak süreci desteklemişlerdir. Daha sonra öğretmen bütün çözümleri sıra ile göstererek aşağıdaki ifadeleri kullanmıştır.

Öğretmen: "İşse arkadaşlar geliştirdiğiniz çözüm yollarına genel olarak bakacak olursak minik serçelerin geliştirdiği formül ve çizim Thales 2, çıraklar ve kızların geliştirdiği formül ise Thales 1 olarak geçmektedir. Böylece siz bunları kendiniz keşfetmiş oldunuz."

Diyalogdan da anlaşıldığı üzere öğretmen, öğrenci çözümlerinin matematikte hangi formüle karşılık geldiği hakkında bilgilendirmeler yapmıştır. Böylelikle öğretmen ve öğrenciler aktif ve sorgulayıcı bir bakış açısıyla birbirlerinin çözümlerine yaklaşarak, çeşitli katkılarda bulunup işbirliği aşamasının genelleştirilmesi tamamlanmıştır.

Genelleştirme basamağında beşinci ve son basamak olarak transfer aşamasındaki grup çözümleri tahtaya yansıtılarak öğretmenle birlikte incelenmiştir. Transfer aşaması uygulanırken önce bireysel çözüm yapmaları daha sonra problem durumu hakkında grup sözcüleri aracılığıyla grupların sınıf ortamında çözümlerini paylaşmaları bu aşamanın genelleştirmesine olumlu yönde katkı sağladığı gözlemlenmiştir. 


\section{Tartışma, Sonuç ve Öneriler}

Çalışmada REACT+G öğretim stratejisi benimsenerek yürütülen “Thales Paralellik İlkesi" konusunun öğretimi sonucunda, araştırmacı ve öğrenciler tarafından edinilen deneyim ve yaşantıların, bu stratejide yer alan "İlişkilendirme", "Tecrübe Etme", “Uygulama”, "İşbirliği”" , “Transfer Etme” ve “Genelleştirme” aşamalarında ne gibi anlamlar ortaya çıkardığına ve bu süreçlerin nasıl gerçekleştiğine odaklanılmıştır. Bu kapsamda elde edinilen bulguların ilgili literatür bakımından tartışma ve sonuçları ise aşamalara göre yapılmıştır.

İlişkilendirme basamağında öğrenciler, önceden sahip oldukları bilgilerle bağlam temelli problem durumunu ilişkilendirdikleri görülmüştür. İlişkilendirmeyi yaparken de farklı ön bilgilerini kullandıkları tespit edilmiştir. Bu noktadan hareketle öğrencilerin ilişkilendirme basamağı için uygulanan çalışma kâğıdının konuyla günlük yaşam arasında ve konuyla seçilen bağlam arasında bağlantı kurmada yardımcı olduğu söylenebilir (Karslı \& Yiğit, 2015). Ayrıca literatürde REACT stratejisine göre işlenen derslerin öğrencilerin günlük yaşamla öğrenilen kavram arasında bağlantı kurmalarına yardımcı olduğunu gösteren çalışmalar da bu sonucu destekler niteliktedir (Demircioğlu \& Özdemir, 2019; Karslı \& Yiğit, 2015).

Tecrübe etme basamağında ise öğrenciler, diğer basamaklara göre daha istekli oldukları gözlemlenmiştir. Tecrübe etme basamağı için hazırlanan çalışma kâğıdındaki yönergelerle sınıf dışı bir ortamda öğrencilerin arkadaşlarıyla birlikte ölçümler yaparak sonuçlara ulaşmaya çalıştıkları, elde ettikleri ölçümlerin yakın çıktığını fark ettikleri ve keşfederek öğrenmeye çalıştıkları tespit edilmiştir. Bu durum çalışmanın genelinde yapılan etkinliklerin öğrencilerin yaparak yaşayarak öğrenmelerini sağlayarak soyut pek çok matematiksel kavramın somutlaştırılarak öğrenilmesinden kaynaklanabilir. Nitekim bağlam temelli etkinliklerin kullanıldı̆̆ı pek çok çalışmada soyut kavramların somutlaştırılarak daha açık ve kolay anlaşılabilir hale geldiği belirtilmektedir (Ayvacı, Ültay \& Mert, 2013; Demircioğlu \& Özdemir, 2019). Ayrıca bağlam temelli bazı çalışmalarda öğrencilerin uygulamaları kendilerinin yapmış olmalarının verdiği özgüven de bilginin anlamlı öğrenilmesine katkı sağladığı ifade edilmektedir (Baran, 2013; Kutu \& Sözbilir, 2011).

Dersin uygulama basamağında öğrenciler, kendilerine yöneltilen problem durumunu daha iyi anlama adına tecrübe etme basamağında yaptıkları gibi şekilsel çizimler yaptıkları 
görülmüştür. Bu yaptıkları çizim ve hesaplamaların sonucu incelendiğinde bütün öğrencilerin uygulama basamağındaki bağlam temelli problem durumuna yönelik doğru çözüm ürettikleri tespit edilmiştir. Tecrübe etme basamağındaki yaparak yaşayarak öğrendikleri bilgileri uygulama basamağına yansıtmaları, uygulama ve daha önceki aşamaların öğrencilerin REACT+G ile yapılan öğrenmenin amacına ulaştığının göstermektedir. REACT+G, öğrencinin aktif olduğu bilginin anlamlı öğrenilmesini sağlayan yapılandırmacı öğrenme yaklaşımını temele almaktadır. Nitekim yapılan pek çok çalışmada yapılandırmacı öğrenme yaklaşımı ile yapılan matematik öğretiminin kalıcı öğrenmeyi sağladığını göstermektedir (Şahiner, 2013). Öğrencilerin tamamının problem durumunu anlamak adına tecrübe etme basamağındaki gibi şekilsel çizimler yapmaları bilgiyi özümsediklerini göstermektedir. Dolayısıyla bu aşama ile öğrencilerin herhangi bir bilgiyi ezberlemenin aksine günlük yaşamla ilişkili problem durumuna yönelik öğrenilen bilgilerin ve edinilen tecrübelerin problemi çözmede kullanılabildiği söylenebilir (Karslı \& Yiğit, 2016).

Öğrenciler sınıf dışı etkinlik ve grup çalışması gerektiren işbirliği basamağında ise çalışma kâğıdında yer alan bağlam temelli problem durumuna yönelik ön hazırlık yaptıkları ve farklı çözüm yolları önerdikleri gözlemlenmiştir. Bu durum öğrencilere hazır bilgi vermek yerine bu bilgilere ulaşmayı sağlayacak becerilerin kazandırılması, grup çalışması, işbirliği içinde çalışmaları ve öğrencilerin teşvik edilmesinden kaynaklanmış olabilir. Nitekim işbirliği aşamasındaki bu durum bağlam temelli pek çok çalışmanın sonuçlarıyla örtüşmektedir (Baran, 2013; Obay \& Çelik, 2019; Ültay, 2014).

Transfer etme basamağı için hazırlanan çalışma kâğıdında yer alan bağlam temelli problem durumundan elde edilen veriler incelendiğinde öğrencilerin bilgiyi bir bağlamdan karşılaşmadıkları diğer bağlama transfer edebildikleri tespit edilmiştir. Böylece öğrenilen bilgilerin derinleştirilmesinin sağlandığı söylenebilir (Karslı \& Yiğit, 2016). Nitekim Richey (2000) çalışmasında bağlamların bilginin uygulanmasını ve transferini kolaylaştırdığını ifade etmiştir. Bu yönüyle okulda öğrenilen bilgilerin günlük yaşama adapte edilerek öğrencilere aktarılması son derece önemlidir. Çünkü öğrencilerin günlük hayattan karşılaştıkları bağlamları çözememelerinin nedeni okulda öğrenilen bilgilerin hayata ve farklı durumlara transfer edilememesine bağlanmıştır (Burbules \& Linn, 1991).

Yapılan öğretimin genelleştirme basamağında ise öğrencilerin REACT'ın aşamalarındaki bağlam temelli problem durumlarına yönelik ürettikleri çözümler, öğretmen 
önderliğindeki bir tartışma ortamı içerisinde sırası ile incelenmiştir. Sürece dair incelemeler yapılırken sınıf ortamında eleştirel bir bakış açısı sonunda öğretmenle birlikte ortak bir karar oluşturmaya çalışılmıştır. Bu sayede öğrencilerin elde ettikleri çözüm, öğretmen tarafından matematik literatürüne uygun şekilde ifade edilmiş ve kurumsal bir statü kazanmıştır. Böylelikle bilgi sınıfın ortak kültürünün bir elemanı haline gelmiştir. Bu süreçte öğretmen, eksik veya yanlış olan noktaların doğrusunu öğrencilerin kendilerinin keşfetmeleri için yönlendirici yardım (scaffolding) ile bir rehber rolünü üstlenmektedir (Crawford, 2001). Ültay (2012) tarafından REACT stratejisinin 5E modeliyle karşılaştırıldığ 1 çalışmada REACT öğretim stratejisinde öğretmenin sürece dahil olarak yönlendirici konumunda olduğu herhangi bir basamağın mevcut olmadığı belirtilmektedir. Dolayısıyla REACT öğretim stratejisinin, öğretim esnasında öğrencilerde meydana gelebilecek yanlış ve eksik öğrenmeleri anında gidermede zayıf kaldığı söylenebilir. REACT stratejisindeki bu zayıf noktayı gidermek adına literatürde yapılan bazı çalışmalar REACT stratejisine bir basamak daha eklenmesi gerektiğini belirtmektedir (Coştu, 2009; Ültay, 2012; Ültay \& Alev, 2017). Dolayısıyla bu çalışma ile REACT stratejisine eklenilmesi ön görülen genelleştirme basamağında öğretmenin öğretim sürecine direkt açıklama yaparak müdahalesi söz konusu değildir. Genelleştirme basamağının amacı öğretim esnasında öğrencilerin istenilen hedefe ulaşılamadığı durumlarda ya da yanlış ve eksik öğrenmeler meydana geldiğinde REACT'ın yapılandırmacı ruhuyla uyumlu bir şekilde öğrencilerin bütün öğretim sürecinde kendi yaptıklarını gözden geçirmelerine imkân tanıyarak bir öz değerlendirme yapmalarını sağlamaktır. Böylece genelleştirme basamağı öğretmene REACT stratejisindeki moderatörlük rolüne ek olarak yaşantılara müdahale etmeden öğretim sürecinin sonunda doğru ve eksikleri keşfetmede rehberlik etme imkânı vermektedir (Davidson, 1990).

Genelleştirme basamağının öğretim süreci sonunda öğrencileri doğruya yönlendirmeye olanak tanıması bu çalışmayla önerilen REACT+G'nin en kuvvetli tarafını oluşturmaktadır. Nitekim bazı çalışmalarda rehber eşliğinde yapılan keşiflerin ve amaçlı (scaffolded) araştırmaların, açık uçlu keşiflerden çok daha fazla etkili olduğunu belirtmektedir (Coştu, 2009). Ayrıca genelleştirme basamağının özellikle REACT'ın en son aşamasında yer alması gerektiği ön görülmektedir. Bunun sebebi öğrencinin hem kendisinin hem de diğer arkadaşlarının bütün öğretim sürecindeki yaşantılarını aşama aşama gözden 
geçirerek karşılaştırma yapmasını sağlamaktır. Böylece bilgi, bireysellikten çıkarılıp sınıfa mal edilerek genelleştirilir.

$\mathrm{Bu}$ çalışmada ilişkilendirme, uygulama ve transfer aşamalarının genelleştirilmesi yapıldı ̆̆ında öğrencilerin tamamının bu aşamalarda başarılı olduğu görülmüştür. Tecrübe etme ve işbirliği aşamasının genelleştirilmesi yapılırken bazı grupların yaptıkları çözümlerde eksiklikler olduğu öğrenciler tarafından fark edilmiştir.

Tecrübe etme ve işbirliği aşamasının genelleştirmesinde bu aşamalardaki problem durumlarına yönelik çözümler sınıfça değerlendirilmiştir. Tam anlamıyla başarıya ulaşamayan gruplar doğru cevap veren grubun çözümünü inceledikten sonra eksikliklerini fark etmişlerdir. Özellikle işbirliği aşamasının genelleştirmesinde öğrenciler fark ettikleri eksikleri gidermeye yönelik bir çaba içerisine girdikleri ve yeniden çözüm önerileri sundukları görülmüştür. Yani öğrenciler bu aşamada bilgiyi yapılandırmacılıkla birbirlerinden öğrendikleri söylenebilir. Nitekim Fer ve Cırık (2007) öğrencilerin bilgiyi sosyal yapılandırmacı bir yapı içerisinde öğrenirken birbirleriyle paylaşarak oluşturdukları bilginin anlamını, diğer bireylerin fikirlerinden etkilenerek geliştirebildikleri belirtmişlerdir. Dolayısıyla bu aşamada yapılan faaliyet sonucu meydana gelen öğrenmelerin sosyal yapılandırmacı bir öğrenme olduğu söylenebilir. REACT+G stratejisine yönelik çalışma yapmak isteyen araştırmaçlara ve çalışmadan elde edilen sonuçlar ışı̆̆ında aşağıdaki öneriler sunulmuştur:

- $\quad$ REACT+G öğretim stratejisine yönelik örnek öğretim tasarımları yapılarak öğretmen yetiştirme programlarına (hizmet öncesi ve hizmet içi) dâhil edilebilir. Böylece REACT+G öğretim stratejisine yönelik öğretmen ve öğretmen adaylarına gerekli bilgiyi kazanma ve uygulama fırsatı sunulabilir. Ayrıca bu tür dersler üzerinden hizmet öncesi dönemle ilgili gerekli araştırmalar yürütülebilir. Bu kapsamda yapılacak çalışmalarla öğretmen ve öğretmen adaylarının REACT+G stratejisine yönelik algıları ile ileride uygulamaya yönelik düşüncelerini ve bunlara etki eden faktörler ortaya çıkarılabilir.

- Yapılan bu çalışmada öğrencilerin tamamının ilişkilendirme, uygulama ve transfer etme aşamasında karşılaştıkları bağlam temelli problemlerim durumlarının çözümünde başarılı olduğu görülmüştür. Tecrübe etme ve işbirliği aşamasında ise öğretim sürecinde bazı öğrencilerin problem durumlarının çözümünde sıkıntı 
yaşadıkları belirlenmiştir. Öğrencilerin bu aşamalarda yaşadıkları öğrenme zorluklarını gidermek adına çalışmada genelleştirme aşamasının REACT stratejisine eklenmesi gerektiği önerilmektedir.

- Öğrenciler öğretim sürecinde yapılandırmacı öğrenme yaklaşımına alışık olmadığından sürekli "doğru" ya da "yanlış" şeklinde öğretmenden dönüt vermesini beklemektedir. Bu durumun gidermek için $\mathrm{REACT}+\mathrm{G}$ stratejisi ile yapılan öğretim için hazırlanan çalışma kâğıtlarına öğrencileri doğru-yanlış kaygısını gidermek için bazı yönergeler eklenmelidir.

- Öğrencilerinin tamamının başarılı olduğu basamaklar incelendiğinde ilişkilendirme basamağında öğrencilerin dikkatini çekmek amacıyla "futbol” bağlamı kullanılarak özellikle öğrencilerin yakın çevresindeki bir futbol karakterine yer verilmiştir. Bu durum öğrencilerin dikkatini çekerek ilişkilendirme basamağının etkili bir şekilde gerçekleşmesini sağlamıştır. Dolayısıyla ilişkilendirme basamağında oluşturulacak bağlamların genel anlamada yaşantısal olmasının yanı sıra her öğrencinin özel olarak değer verdiği, takip ettiği yakın çevresindeki kişilerden ya da olaylardan seçilmesi bu aşamanın daha etkili sonuçlar vermesi için önerilebilir.

Uygulama ve transfer etme basamaklarında öğrencilerin tamamının başarılı olmasında bu basamaklardan önceki aşamaların etkili bir şekilde gerçekleştiği görülmüştür. Özellikle tecrübe etme ve işbirliği aşamasında öğrencilerin görev paylaşımı yaparak öğretimde sorumluluk almaları öğrencilerin başarısında bir etken olduğu düşünülmektedir. Dolayısıyla mümkün olduğunca her aşamanın öğrencilere kendi öğrenmelerinde sorumluluk verilecek şekilde tasarlanması gerektiği söylenilebilir.

\section{Bilgilendirme}

Bu çalışmada kullanılan veriler 2020 yılı öncesine ait olduğu araştırmacılar tarafından onaylanmıştır.

\section{Yazar Katkı Beyanı}

Mehmet İhsan YURTYAPAN: Literatür tarama, Etkinlik Geliştirme, Veri Toplama ve Analizi, Uygulama, Ön Taslak Yazımı ve Düzenleme

Menekşe Seden TAPAN-BROUTIN: Metodoloji, Danışmanlık ve Denetim, İncelemeYazma ve Düzenleme

Gül KALELI-YILMAZ: Metodoloji, Danışmanlık ve Denetim, İnceleme-Yazma ve Düzenleme 


\section{Kaynaklar}

Aydoğdu, M. \& Ayaz, M. F. (2008). Matematikte öğrencilere problem çözme yeteneğinin kazandırılması. e-Journal of New World Sciences Academy Social Sciences, 3(4), 588-596.

Ayvacı, H. Ş., Ültay, E. \& Mert, Y. (2013). Dokuzuncu sinıf fizik kitabında yer alan bağlamların değerlendirilmesi. Necatibey Eğitim Fakültesi Elektronik Fen ve Matematik Ĕ̈itimi Dergisi, 7(1), 242-263.

Baran, M. (2013). Yaşam temelli probleme dayalı öğretim yönteminin termodinamik konusunun öğretimine etkisi. (Yayımlanmamış doktora tezi), Atatürk Üniversitesi, Erzurum.

Berns, R. G. \& Erickson, P. M. (2001). Contextual teaching and learning: Preparing students for the new economy. The Highlight Zone Research Work. 5, 1-8.

Burbules, N. C. \& Linn, M. C. (1991). Science education and philosophy of science: Congruence or contradiction?. International Journal of Science Education, 13(3), 227- 241.

Cansoy, R. (2018). Uluslararası çerçevelere göre 21. yüzyıl becerileri ve eğitim sisteminde kazandırılması. Insan ve Toplum Bilimleri Araştırmaları Dergisi, 7(4), 3112-3134.

Demircioğlu, H. \& Özdemir, R. (2019). Bağlam temelli öğrenme yaklaşımının öğretmen adaylarının nanoteknoloji konusunu anlamaları üzerindeki etkisi. Journal of Computer and Education Research, 7 (14), 314-336. DOI: 10.18009/jcer.576978

Tekin, B. \& S. Tekin (2004). Matematik öğretmen adaylarının matematiksel okuryazarlık düzeyleri üzerine bir araştırma. MATDER. Alınan yer http://www.matder.org.tr/matematik-ogretmen-adaylarinin-matematiksel-okuryazarlikduzeyleri-uzerine-bir-arastirma/

Uysal, E. \& Yenilmez, K. (2011). Sekizinci sinıf öğrencilerinin matematik okuryazarlığ düzeyi. Eskişehir Osmangazi Üniversitesi Sosyal Bilimler Dergisi, 12(2), 1-15.

Civelek, Ş., Meder, M., Tüzen, H. \& Aycan, C. (2003). Matematik öğretiminde karşılaşılan aksaklıklar. Alınan yer http://www.matder.org.tr/matematik-ogretiminde-karsilasilanaksakliklar/

CORD, (1998). CORD algebra 1: Mathematics in Context, Cincinati: South-Western Educational Publishing.

Coştu, S. (2009). Matematik öğretiminde bağlamsal öğrenme ve öğretme yaklaşımına göre tasarlanan öğrenme ortamlarında öğretmen deneyimleri. (Yayımlanmamış yüksek lisans tezi), Karadeniz Teknik Üniversitesi, Trabzon.

Crawford, M. L. (2001). Teaching contextually: Research, rationale, and techniques for improving student motivation and achievement in mathematics and science. Waco, Texas: CCI Publishing.

Davidson, N. (1990). Cooperative Learning in Mathematics: A Handbook for Teachers.Menlo Park CA: Addison-Wesley Publishing.

Fer, S. \& Cırık, İ. (2007). Yapılandırmacı Öğrenme Kuramdan Uygulamaya.(1. Baskı). İstanbul: Morpa Yayınları. 
Heller, P. M., Ahlgren, A., Post, T., Behr, M. \& Lesh, R. (1989). Proportional reasoning: The effect of two context variables, rate type, and problem setting. Journal of Research in Science Teaching,26(3), 205-220.

Hull, D. (1999). Teaching mathematics contextually: The cornerstone of tech prep. USA: Cord Communication.

Ingram S. J. (2003). The effects of contextual learning instruction on science achievement of male and female tenth grade students, (Unpublished Phd thesis), University of South Alabama, Instructional Design and Development, USA.

Işık, A., Çiltaş, A., \& Bekdemir, M. (2008). Matematik eğitiminin gerekliliği ve önemi. Atatürk Üniversitesi Kazım Karabekir Eğitim Fakültesi Dergisi, 17, 174-184.

Karamustafaoğlu O. \& Tutar M. (2018). REACT stratejisine dayalı bağlam temelli fen öğretimi. O. Karamustafaoğlu, Ö. Tezel \&e U. Sarı (Ed.), Güncel yaklaşım ve yöntemlerle etkinlik destekli fen öğretimi (ss.198-217). Ankara: Pegem Akademi.

Karsl1, F. \& Yiğit, M. (2016). 12th grade students' views about an alkanes worksheet based on the REACT strategy. Necatibey Faculty of Education Electronic Journal of Science $\mathcal{E}$ Mathematics Education, 10(1), 472-499.

Karslı, F. (2011). Fen bilgisi öğretmen adaylarının bilimsel süreç becerilerini geliştirmesinde ve kavramsal değişim sağlamasında zenginleştirilmiş laboratuar rehber materyallerinin etkisi. (Yayınlanmamış doktora tezi). Karadeniz Teknik Üniversitesi, Trabzon.

Karslı, F. \& Yiğit, M. (2015). Lise 12. sınıf öğrencilerinin alkanlar konusundaki kavramsal anlamalarına bağlam temelli öğrenme yaklaşımının etkisi. İnönü Üniversitesi Ĕ̆gitim Fakültesi Dergisi,16(1), 43-61.

Kurdal, C. (2016). Dinamik ve etkileşimli matematik öğrenme ortamlarında öğrencilerin kesirler ve oran orantı konusunda yaptı̆̆̆ hatalar ve çözüm önerileri.(Yayımlanmamış yüksek lisans tezi), Bayburt Üniversitesi, Bayburt.

Kutu, H. \& Sözbilir, M. (2011). Yaşam temelli ARCS öğretim modeliyle 9. sınıf kimya dersi "Hayatımızda kimya" ünitesinin öğretimi. Ondokuz Mayıs Üniversitesi Eğitim Fakültesi Dergisi, 30(1), 29-62.

Lynch, R. L. \& Padilla, M. J. (2000). Contextual teaching and learning in preservice teacher education. Washington DC: University of Georgia

Mertler, C.A. \& Charles, C.M. (2011) Introduction to educational research (7th Edition). Boston: Allyn \& Bacon.

Miles, M. B. \& Huberman, A. M. (1994). Qualitative data analysis: an expanded sourcebook. New York: Sage.

Milli Eğitim Bakanlığ1 [MEB], (2018). Ortaöğretim matematik dersi (9, 10, 11 ve 12.sınıflar) öğretim programı. Ankara: Devlet Kitapları Basım Evi.

Navarra, A. (2006). Achieving pedagogical equity in the classroom.Waco, Texas: Cord Publishing.

Obay, M. \& Çelik, H.C. (2019). İlköğretim matematik öğretmen adayları bağlam temelli öğrenme hakkında ne düşünüyor? Nitel bir araştırma. Journal of Computer and Education Research, 7 (14), 284-313. DOI: 10.18009/jcer.574528 
Pakmak, G. S. (2014). 6. sınıf öğrencilerinin niceliksel ve niteliksel orantısal akıl yürütme problemlerinin çözümündeki anlayışlarının incelenmesi.(Yayımlanmamış yüksek lisans tezi), Pamukkale Üniversitesi, Denizli.

Patton, M. Q. (2014). Nitel araştırma ve değerlendirme yöntemleri. (Çev. Bütün, M. ve Demir, S. B.). Ankara: Pegema Akademi.

Pilot, A. \& Bulte, A. M. W. (2006). Why do you "need to know"? Context-based education. International Journal of Science Education, 28(9), 953-956.

Richey, R. C. (2000). The future role of Robert M. Gagné in instructional design. In R. C. Richey (Ed.), The Legacy of Robert M. Gagné (pp. 255-281). Syracuse, NY: Eric Clearhouse.

Şahiner, A. (2013). 5E modelinin ilköğretim 6. sinıf öğrencilerinin matematik dersi kümeler konusundaki erişi ve kalıcılığına etkisi. (Yayımlanmamış yüksek lisans tezi), Gaziantep Üniversitesi, Gaziantep.

Tekbıyık, A. (2010). Bağlam temelli yaklaşımla ortaöğretim 9. sinıf enerji ünitesine yönelik $5 E$ modeline uygun ders materyallerinin geliştirilmesi.(Yayımlanmamış yüksek lisans tezi), Karadeniz Teknik Üniversitesi, Trabzon.

Texas Collaborative for Teaching Excellence (2007). The REACT Strategy. Alınan yer http://www.texascollaborative.org/TheREACTstrategy.htm

Ültay, E. (2014). Çalışmada itme momentum konusunda REACT stratejisinin öğrencilerin kavramsal anlamlarına olan etkisi.(Yayımlanmamış doktora tezi), Karadeniz Teknik Üniversitesi, Trabzon.

Ültay, E. \& Alev, N. (2017). Açıklama destekli REACT stratejisi ile ilgili öğretmen adaylarının görüşleri. Mersin Üniversitesi Ĕ̆itim Fakültesi Dergisi, 13(2), 803-820.

Ültay, N. (2012). Asit ve baz konusuyla ilgili REACT stratejisine ve 5E modeline göre etkinliklerin geliştirilmesi, uygulanması ve karşılaştırılması.(Yayımlanmamış doktora tezi), Karadeniz Teknik Üniversitesi, Trabzon.

Ültay, N. \& Çalık, M. (2011). Asitler ve bazlar konusu ile ilgili örnekler üzerinden 5E modelini ve REACT stratejisini ayırt etmek. Necatibey Eğitim Fakültesi Elektronik Fen ve Matematik Ĕ̈itimi Dergisi,5(2), 199-220.

Yıldırım, A. \& Şimşek, H. (2016). Sosyal bilimlerde nitel araştırma yöntemleri. (10. Baskı.). Ankara: Seçkin Yayınları. 